\title{
Contribution of emissions to concentrations: the TAGGING 1.0 submodel based on the Modular Earth Submodel System (MESSy 2.52)
}

\author{
Volker Grewe $^{1,2}$, Eleni Tsati ${ }^{1}$, Mariano Mertens ${ }^{1}$, Christine Frömming ${ }^{1}$, and Patrick Jöckel ${ }^{1}$ \\ ${ }^{1}$ Deutsches Zentrum für Luft- und Raumfahrt, Institut für Physik der Atmosphäre, Oberpfaffenhofen, Germany \\ ${ }^{2}$ Delft University of Technology, Aerospace Engineering, Section Aircraft Noise and Climate Effects, Delft, the Netherlands
}

Correspondence to: Volker Grewe (volker.grewe@dlr.de)

Received: 6 December 2016 - Discussion started: 5 January 2017

Revised: 2 May 2017 - Accepted: 7 June 2017 - Published: 10 July 2017

\begin{abstract}
Questions such as "what is the contribution of road traffic emissions to climate change?" or "what is the impact of shipping emissions on local air quality?" require a quantification of the contribution of specific emissions sectors to the concentration of radiatively active species and airquality-related species, respectively. Here, we present a diagnostics package, implemented in the Modular Earth Submodel System (MESSy), which keeps track of the contribution of source categories (mainly emission sectors) to various concentrations. The diagnostics package is implemented as a submodel (TAGGING) of EMAC (European Centre for Medium-Range Weather Forecasts - Hamburg (ECHAM)/MESSy Atmospheric Chemistry). It determines the contributions of 10 different source categories to the concentration of ozone, nitrogen oxides, peroxyacytyl nitrate, carbon monoxide, non-methane hydrocarbons, hydroxyl, and hydroperoxyl radicals ( = tagged tracers). The source categories are mainly emission sectors and some other sources for completeness. As emission sectors, road traffic, shipping, air traffic, anthropogenic non-traffic, biogenic, biomass burning, and lightning are considered. The submodel obtains information on the chemical reaction rates, online emissions, such as lightning, and wash-out rates. It then solves differential equations for the contribution of a source category to each of the seven tracers. This diagnostics package does not feed back to any other part of the model. For the first time, it takes into account chemically competing effects: for example, the competition between $\mathrm{NO}_{x}, \mathrm{CO}$, and non-methane hydrocarbons (NMHCs) in the production and destruction of ozone. We show that the results are in-line with results from
\end{abstract}

other tagging schemes and provide plausibility checks for concentrations of trace gases, such as $\mathrm{OH}$ and $\mathrm{HO}_{2}$, which have not previously been tagged. The budgets of the tagged tracers, i.e. the contribution from individual source categories (mainly emission sectors) to, e.g., ozone, are only marginally sensitive to changes in model resolution, though the level of detail increases. A reduction in road traffic emissions by $5 \%$ shows that road traffic global tropospheric ozone is reduced by $4 \%$ only, because the net ozone productivity increases. This $4 \%$ reduction in road traffic tropospheric ozone corresponds to a reduction in total tropospheric ozone by $\approx 0.3 \%$, which is compensated by an increase in tropospheric ozone from other sources by $0.1 \%$, resulting in a reduction in total tropospheric ozone of $\approx 0.2 \%$. This compensating effect compares well with previous findings. The computational costs of the TAGGING submodel are low with respect to computing time, but a large number of additional tracers are required. The advantage of the tagging scheme is that in one simulation and at every time step and grid point, information is available on the contribution of different emission sectors to the ozone budget, which then can be further used in upcoming studies to calculate the respective radiative forcing simultaneously.

\section{Introduction}

Nitrogen oxides $\left(\mathrm{NO}_{x}\right)$, carbon monoxide $(\mathrm{CO})$, methane $\left(\mathrm{CH}_{4}\right)$, and non-methane hydrocarbons (NMHCs) are precursors of tropospheric ozone $\left(\mathrm{O}_{3}\right)$. The assessment of the con- 
tribution of individual emissions of these precursors on air quality and climate requires a detailed analysis of the chemical conversion, transport, and deposition of these species in numerical atmosphere-chemistry simulations. A frequently used method is called "tagging" (Horowitz and Jacob, 1999; Lelieveld and Dentener, 2000; Meijer et al., 2000; Dunker et al., 2002; Grewe, 2004; Gromov et al., 2010; Butler et al., 2011; Emmons et al., 2012; Grewe et al., 2012). Technically, this method adds a set of diagnostic tracers for each chemical species or chemical family considered, i.e. one additional tracer per source category for each chemical species or family considered. For example, for the family of reactive nitrogen compounds $\mathrm{NO}_{y}$, a set of tagged tracers $\mathrm{NO}_{y}^{\text {ant }}, \mathrm{NO}_{y}^{\mathrm{rt}}$, $\mathrm{NO}_{y}^{\text {shp }}, \mathrm{NO}_{y}^{\text {air }}, \mathrm{NO}_{y}^{\text {bio }}, \mathrm{NO}_{y}^{\text {bb }}, \mathrm{NO}_{y}^{\text {lig }}, \mathrm{NO}_{y}^{\mathrm{CH}_{4}}, \mathrm{NO}_{y}^{\mathrm{N}_{2} \mathrm{O}}$, and $\mathrm{NO}_{y}^{\text {str }}$ is added, which describes the $\mathrm{NO}_{y}$ concentration from anthropogenic non-traffic (e.g. industry, households), road traffic, ships, air traffic, biogenic, biomass burning, lightning, methane and nitrous oxide decomposition, and stratospheric ozone production. The idea is that these tagged tracers experience the same chemical conversions, sources, and loss processes (such as deposition) as the simulated tracer $\mathrm{NO}_{y}$. If all emissions of $\mathrm{NO}_{y}$ are considered and tagged, the sum of all tagged diagnostic $\mathrm{NO}_{y}$ tracers equals the simulated $\mathrm{NO}_{y}$ tracer in this approach. A full partition of the simulated tracer concentration with respect to emission sectors can be achieved. Thus, the contribution of an emission sector, such as industry, road traffic, etc., to a concentration is provided by the tagging method.

The abundances of carbon compounds $\left(\mathrm{CO}, \mathrm{CH}_{4}\right.$, NMHCs) and nitrogen oxides are both limiting factors for tropospheric ozone production (Sillman, 1995). Many tagging mechanisms for global applications concentrate on $\mathrm{NO}_{x}$ compounds (Horowitz and Jacob, 1999; Lelieveld and Dentener, 2000; Meijer et al., 2000; Grewe, 2004; Grewe et al., 2012) only. Butler et al. (2011) tags the sources for hydrogen carbons. Dunker et al. (2002) tags ozone sensitivities and attributes them to either nitrogen oxides or volatile organic compounds (VOCs) depending on the chemical regime. This latter mechanism is a very helpful tool in understanding the underlying chemical processes and especially sensitivities. However, the mechanism differs in principle from other tagging mechanisms. One consequence is that the sum of all contributions is not adding up to the ozone concentration. The focus on the ozone sensitivities makes that scheme more similar to the perturbation approach.

This perturbation approach (e.g. Hoor et al., 2009; Grewe et al., 2007, and many others), where results from two simulations are compared that differ in the strength of an individual emission source, identify the impact of changes in emissions (e.g. by mitigation options) on the atmospheric composition. It is important not to confuse both approaches. For example, the change in ozone due to a $100 \%$ reduction in road traffic emissions is smaller by a factor of 5 than the contribution of the road traffic emissions to ozone (Grewe et al.,
2012). Emmons et al. (2012) showed that similar results (factor of 3) are obtained for biomass burning $\mathrm{NO}_{x}$ emissions and the impact on ozone. Clearly, the non-linearity in the ozone chemistry leads to these large differences. Any reduction in $\mathrm{NO}_{x}$ emission leads mostly to a larger ozone production efficiency. Grewe et al. (2012) showed that in the simulation without road traffic $\mathrm{NO}_{x}$ emissions, the obvious large reduction in ozone from the reduced road traffic contribution to ozone is compensated by larger contributions from other emission sectors, not because these emissions are changed, but because the ozone production efficiency is increased.

These two different approaches answer two different questions. The perturbation approach quantifies how much a concentration changes if emissions are changed, whereas tagging addresses the contribution of an emission to the concentration. The combination of both approaches leads to much better insights in the reasons how emission changes lead to concentration changes (Grewe et al., 2012). Note also that the perturbation approach often requires the identical meteorology in either simulation to enhance the signal-to-noise ratio enabling a robust signal. However, this is not feasible in fully coupled chemistry-climate models unless run in a "QCTMmode", which replaces instantaneous chemical feedbacks by climatological values (Deckert et al., 2011, see also below).

Most tagging approaches address a straight process chain from the emission of, e.g., $\mathrm{NO}_{x}$ to a concentration of, e.g., ozone. Grewe et al. (2010), as well as Grewe (2013a) and Tsati (2014), proposed a more general tagging approach, where competing mechanisms in the production of ozone can be taken into account; e.g. both $\mathrm{NO}_{x}$ and carbon compounds $\left(\mathrm{CO}, \mathrm{CH}_{4}, \mathrm{NMHCs}\right)$ are precursors of ozone. This more general tagging approach allows the contribution of road traffic $\mathrm{NO}_{x}, \mathrm{CO}$, and NMHC emissions to ozone, for example, to be determined. This generalised method has also been successfully applied to a non-chemical application, namely temperature in an energy balance model (Grewe, 2013b).

Here, we present a submodel (TAGGING) of an Earth system model (EMAC - European Centre for Medium-Range Weather Forecasts - Hamburg (ECHAM)/MESSy Atmospheric Chemistry), which applies this general tagging approach to allow the contribution of $\mathrm{NO}_{x}, \mathrm{CO}$, and NMHC emissions from a variety of emission sectors to ozone and $\mathrm{HO}_{x}$ chemistry to be quantified. Hence, it combines $\mathrm{NO}_{x}$ ozone tagging approaches (Emmons et al., 2012) with VOCozone tagging approaches (Butler et al., 2011). In Sect. 2 we present the basic equations of the tagging scheme, whereas in Sect. 3 we present what emissions are addressed and how the tagging method is implemented. In Sect. 4 we show results of a base simulation and compare them with other modelling studies. Since no measurements are available for contributions of emissions to ozone concentrations, a direct comparison with observational data is not possible. Instead, we show that the results are in agreement with other studies. Since the tagging of $\mathrm{HO}_{x}$ components is new, we discuss those results in more detail, especially with the focus on aviation 
and shipping emissions. Finally, we address sensitivities of the methodology (Sect. 5), with respect to the resolution and emission changes, and provide a comparison of the perturbation and tagging method.

\section{Basics on tagging}

The tagging approach that we adopt here is based on Grewe et al. (2010) and Grewe (2013a). We first describe the basic mechanism and describe in Sect. 3 how this mechanism is applied in the submodel TAGGING. Exemplarily, we concentrate on the main reaction for tropospheric ozone production:

$\mathrm{NO}+\mathrm{HO}_{2} \longrightarrow \mathrm{NO}_{2}+\mathrm{OH}$.

Note, this reaction is not producing any ozone, but $\mathrm{NO}_{2}$ is photolysed and recombines with $\mathrm{O}_{2}$ to form ozone and Reaction (R1) is the rate limiting step for this chain of reactions. The ozone production rate $P_{\mathrm{R} 1}$ depends on the abundance of $\mathrm{NO}$ and $\mathrm{HO}_{2}$, and the reaction rate coefficient $k_{\mathrm{R} 1}$ (Reaction R1). The NO concentration in turn depends on emissions of NO from different emission sectors (here $N$ in total), such as industry and road traffic with the respective concentration $\mathrm{NO}_{x}^{\text {ind }}$ and $\mathrm{NO}_{x}^{\mathrm{rt}}$. Thus, the ozone production rate $P_{\mathrm{R} 1}$ has to be distributed to the sectors: industry, road traffic, etc. This is achieved by a combinatoric redistribution according to the concentrations of the tagged family and species of $\mathrm{NO}_{x}$ and $\mathrm{HO}_{2}$, respectively. Note that a full description of the applied TAGGING mechanism, including the tagging of $\mathrm{OH}$ and $\mathrm{HO}_{2}$, is given in the next section. This means that all possible combinations between a tagged $\mathrm{NO}_{x}$ species and another tagged $\mathrm{HO}_{2}$ species are evaluated and its probability calculated consistently with the calculation of the chemical production rate $P_{\mathrm{R} 1}$. This is just a full partitioning of the production rate $P_{\mathrm{R} 1}$ Grewe et al. (following 2010):

$$
\begin{aligned}
P_{\mathrm{R} 1}= & k_{\mathrm{R} 1} \mathrm{NOHO}_{2}, \\
= & k_{\mathrm{R} 1} \sum_{i=1}^{N} \mathrm{NO}^{\mathrm{i}} \sum_{j=1}^{N} \mathrm{HO}_{2}{ }^{j}, \\
= & k_{\mathrm{R} 1} \sum_{i=1}^{N}\left(\mathrm{NO}^{i} \mathrm{HO}_{2}^{i}+\sum_{j \neq i} \frac{1}{2} \mathrm{NO}^{i} \mathrm{HO}_{2}^{j}\right. \\
& \left.+\sum_{j \neq i} \frac{1}{2} \mathrm{NO}^{j} \mathrm{HO}_{2}^{i}\right), \\
= & \sum_{i=1}^{N} \frac{1}{2} k_{\mathrm{R} 1}\left(\frac{\mathrm{NO}^{i}}{\mathrm{NO}^{i}}+\frac{\mathrm{HO}_{2}{ }^{i}}{\mathrm{HO}_{2}}\right), \\
= & \sum_{i=1}^{N} P_{\mathrm{R} 1}^{i} .
\end{aligned}
$$

Here $i$ and $j$ represent a counter for all $N$ source categories; we have chosen $N=10$ source categories (see Sect. 3). The factor $\frac{1}{2}$ stems from the split of the part of the ozone production $k_{\mathrm{R} 1} \mathrm{NO}^{i} \mathrm{HO}_{2}{ }^{j}(i \neq j)$, which is equally attributed to emission category $i$ and $j$. Note that no approximation, linearisation, or Taylor approximation is used in this approach. For the ozone production due to $\mathrm{NO}_{x}$ from industry $\left(\mathrm{NO}_{x}^{\text {ind }}\right.$ ) and due to $\mathrm{HO}_{2}^{\text {ind }}$ from industry we hence obtain:

$P_{\mathrm{R} 1}^{\text {ind }}=P_{\mathrm{R} 1} \frac{1}{2}\left(\frac{\mathrm{NO}^{\text {ind }}}{\mathrm{NO}}+\frac{\mathrm{HO}_{2}^{\text {ind }}}{\mathrm{HO}_{2}}\right)$.

Note that this includes the reactions of $\mathrm{NO}_{x}^{\text {ind }}$ with all other $\mathrm{HO}_{2}$ molecules and vice versa $\mathrm{HO}_{2}^{\text {ind }}$ with other $\mathrm{NO}_{x}$ molecules without any double counting. The relevant differential equation for the tagged species is then

$\frac{\mathrm{d}}{\mathrm{d} t} \mathrm{O}_{3}^{\text {ind }}=P^{\text {ind }}-D^{\text {ind }}$,

where $P^{\text {ind }}$ and $D^{\text {ind }}$ are the sum of all relevant production and loss terms. With this approach, Grewe et al. (2010) showed that the sum of all emissions contributions adds up to the total concentration of the respective species. For example, the ozone field is completely partitioned into emission sector contributions, if all emission sectors are included, leading to

$\sum_{i=1}^{N} \mathrm{O}_{3}{ }^{i}=\mathrm{O}_{3}$.

Note that the factor 0.5 in Eq. (6) is a result of the combinatorical ansatz and not an assumption. It reflects that in Reaction (R1) both species are required and similar to the reaction rate coefficient it constitutes a basic principle. This should not be confused with effects of different chemical regimes on the ozone productivity, which are reflected in the concentrations of ozone and the tagged ozone fields. For example, when increasing $\mathrm{NO}_{x}$ emissions in a VOClimited regime (i.e. any changes in nitrogen oxide emissions hardly change the ozone production), the ozone productivity or sensitivity attributed to $\mathrm{NO}_{x}$ will decrease, whereas that of VOCs remains unchanged.

This approach is identical to a different formulation, which describes the right-hand side of the differential equation more generally as the relative sensitivity of the individual production and loss terms with respect to the emission sector considered (Grewe, 2013a):

$P_{\mathrm{R} 1}^{\text {ind }}=P_{\mathrm{R} 1} \frac{\boldsymbol{S}^{\text {ind }^{T}} \nabla_{S} P_{\mathrm{R} 1}}{\boldsymbol{S}^{T} \nabla_{S} P_{\mathrm{R} 1}}$,

where $S$ is the vector of all chemical compounds, e.g.

$$
\begin{aligned}
S^{T} & =\left(\mathrm{NO}_{\mathrm{x}}, \mathrm{CO}, \mathrm{NMHC}, \mathrm{O}_{3}, \ldots\right)^{T}, \text { and } \\
S^{\text {ind }}{ }^{T} & =\left(\mathrm{NO}_{x}^{\text {ind }}, \mathrm{CO}^{\text {ind }}, \mathrm{NMHC}^{\text {ind }}, \mathrm{O}_{3}{ }^{\text {ind }}, \ldots\right)^{T},
\end{aligned}
$$


$\nabla_{S} P_{\mathrm{R} 1}=\frac{\mathrm{d}}{\mathrm{d} S} P_{\mathrm{R} 1}$,

providing two different interpretations of the differential Eq. (7).

To summarise, this tagging approach fully partitions individual chemical fields into the contribution of individual emission sectors. There is no linearisation required and the approach utilises the identical chemical parameterisation as the underlying chemical scheme, with respect to the probability that a reaction occurs. Note that the new aspect of this tagging approach compared to other tagging approaches (Grewe, 2007; Lelieveld and Dentener, 2000; Emmons et al., 2012) is the competing effect of $\mathrm{NO}_{x}$ and carbon compounds in producing ozone. Since the differential equation for the tagging Eq. (7) fully relies on the reaction rates and concentrations, the tagging scheme can be implemented independently from the main chemical solver. However, details on many reaction rates have to be transferred from the chemical solver to the tagging scheme.

In the following, and actually this also applies to the previous sections, we use the wording "contribution of emissions from a sector $X$ to the atmospheric concentration of species (or family) $Y$ ", when we are referring to that part of the concentration $Y$, which can be attributed to the emission sector $X$, by a decomposition of the chemical reactions (see above). This implies that no changes in chemical reaction rates are assumed, e.g. for natural and anthropogenic emissions, which would represent different atmospheric situations for pre-industrial and today's atmospheric chemical regimes. Obviously, other authors may have other definitions for this wording.

\section{Implementation in $\operatorname{EMAC/MECO}(n)$}

The objective of the implementation of this tagging scheme is to be able to monitor online, i.e. at every model's time step, the contribution of individual emission sectors to ozone and $\mathrm{OH}$, allowing for a competition between ozone precursors, linearisation to be avoided, and applicable in decadal simulations. The tagging approach requires one to quantify all sources of the species considered. Therefore, in addition to the emission sectors considered, there are additional source categories considered, such as ozone produced by photolysis of oxygen, which predominantly occurs in the stratosphere and which we therefore name stratospheric ozone production. Note that also in the upper troposphere, ozone is produced by this reaction. In the following the base models are described for which the tagging scheme is developed, an overview on the tagging scheme is given, and the tagging chemistry is described.

\subsection{Description of MESSy, EMAC, and $\operatorname{MECO}(n)$}

The TAGGING model described here (see also Tsati, 2014) is written as a submodel of the Modular Earth Submodel
System (MESSy), which comprises a standard interface to couple different processes, a simple coding standard and a set of different submodels (Jöckel et al., 2005). The TAGGING submodel is implemented in MESSy2 (Jöckel et al., 2010) and consists of two parts, the submodel interface layer (SMIL) and the submodel core layer (SMCL). The SMIL part is mainly important for data management, defining and handling the tracers (using the TRACER submodel described in Jöckel et al., 2008), and the diagnostic output fields using the CHANNEL submodel (Jöckel et al., 2010). The coupling for the necessary input fields are also handled via the CHANNEL submodel. These input fields comprise, for example, lightning $\mathrm{NO}_{x}$ emissions, and chemical production/loss rates from the chemical solver MECCA (Module Efficiently Calculating the Chemistry of the Atmosphere; Sander et al., 2011).

The TAGGING submodel is implemented in EMAC and $\operatorname{MECO}(n)$ (MESSyfied ECHAM and the Consortium for Small-Scale Modelling model COSMO nested $n$ times). While EMAC uses ECHAM5 as a global circulation model, $\operatorname{MECO}(n)$ consists of COSMO/MESSy as a regional-scale model with EMAC as the driving model (Kerkweg and Jöckel, 2012a), which are coupled online. The SMCL of the TAGGING submodel is independent of the base model and consists mainly of the code needed to solve the relevant equations. A detailed description of the TAGGING submodel, including individual subroutines of the SMIL and the SMCL, are provided in the supplement. The model set-up is identical to that of Mertens et al. (2016). A detailed list of applied submodels can be found in the supplement of Mertens et al. (2016, p. 42, therein). Table 1 describes only those submodels that are of direct relevance for the TAGGING submodel. An evaluation of the model configurations of EMAC and $\operatorname{MECO}(n)$ with respect to the chemical composition of the atmosphere can be found in Jöckel et al. (2016) and Mertens et al. (2016).

\subsection{TAGGING overview: families, emission sectors, and workflow}

The objective of the tagging scheme is to determine the contribution of emissions from various sectors. Here, we discriminate between 10 different sources: four anthropogenic: non-traffic anthropogenic (industry, energy, households), road traffic, ships, and air traffic; five natural sources: lightning, emissions from biogenic sources including soils, decomposition of $\mathrm{N}_{2} \mathrm{O}$, decomposition of $\mathrm{CH}_{4}$, stratospheric ozone production by photolysis of $\mathrm{O}_{2}$; and a mixed class: biomass burning (see Table 2).

We use a configuration of the chemical scheme MECCA (Sander et al., 2011), which consists of 72 species. We only tag a reduced set of species, which resemble the main species and families for tropospheric chemistry, in order to limit the required memory. Besides $\mathrm{CO}, \mathrm{O}_{3}$, peroxyacytyl nitrate (PAN), $\mathrm{HO}_{2}$, and $\mathrm{OH}$, two families are considered: $\mathrm{NO}_{y}$ and 
Table 1. Brief description of the submodels used together with the TAGGING submodel. A complete list can be found in the supplement of Mertens et al. (2016).

\begin{tabular}{lll}
\hline Submodel & Description & Reference \\
\hline CLOUD & large-scale cloud/rain properties & Based on Roeckner et al. (2003); see also Jöckel et al. (2006) \\
CONVECT & convective cloud/rain properties and related transport & Tost et al. (2006a) \\
DDEP & dry deposition of trace gases & Kerkweg et al. (2006a) \\
JVAL & photolysis rates & Landgraf and Crutzen (1998); see also Jöckel et al. (2006) \\
LNOX & lightning NO NO $_{x}$ emissions & Tost et al. (2007) and Grewe et al. (2001) \\
MECCA & tropospheric and stratospheric gas-phase chemistry & Sander et al. (2011) \\
OFFEMIS & prescribed emissions of trace gases & Kerkweg et al. (2006b) (named OFFLEM therein) \\
ONEMIS & online calculated emissions of trace gases & Kerkweg et al. (2006b) (named ONLEM therein) \\
SCAV & wet deposition and scavenging of trace gases & Tost et al. (2006b) \\
\hline
\end{tabular}

Table 2. Submodels that provide the source terms (emissions or production terms) for the individual emission sectors (first column) and tagged species (columns 2-4).

\begin{tabular}{|c|c|c|c|c|}
\hline \multirow[t]{2}{*}{ Sector } & \multicolumn{4}{|c|}{ Tagged species with emissions and other sources } \\
\hline & $\mathrm{NO}_{y}$ & $\mathrm{CO}$ & NMHC & $\mathrm{O}_{3}$ \\
\hline \multicolumn{5}{|l|}{ Anthropogenic } \\
\hline Non-traffic & OFFEMIS & OFFEMIS & OFFEMIS & - \\
\hline Road traffic & OFFEMIS & OFFEMIS & OFFEMIS & - \\
\hline Ships & OFFEMIS & OFFEMIS & OFFEMIS & - \\
\hline Air traffic & OFFEMIS & OFFEMIS & OFFEMIS & - \\
\hline \multicolumn{5}{|l|}{ Natural } \\
\hline Lightning & LNOX & - & - & - \\
\hline Biogenic & ON-/OFFEMIS & ON-/OFFEMIS & ON-/OFFEMIS & - \\
\hline $\mathrm{N}_{2} \mathrm{O}$ & MECCA & - & - & - \\
\hline $\mathrm{CH}_{4}$ & - & - & MECCA & - \\
\hline Strat- $\mathrm{O}_{3}$ & - & - & - & MECCA \\
\hline \multicolumn{5}{|l|}{ Mixed } \\
\hline Biomass burning & OFFEMIS & OFFEMIS & OFFEMIS & - \\
\hline
\end{tabular}

NMHC, which include all chemically active nitrogen compounds (15) and hydrocarbons (42) (see the Supplement for more details). All together, the tagging scheme consists of 7 species times 10 emission sectors, thus 70 tagged tracers. For each tracer initialisation, transport (except for $\mathrm{OH}$ and $\mathrm{HO}_{2}$ ), emissions, dry and wet deposition, and chemical conversion has to be deduced from the base model (Fig. 1). The tagging scheme utilises the EMAC submodels, e.g. for tracer transport, for emissions computed online during the simulation, and for emissions prescribed by inventories (Table 1; for details see the Supplement), such as industry, road traffic, etc. (Fig. 1, middle column). It further obtains information on online emissions (lightning, soils), dry and wet deposition, background tracers and reaction rates (left column). This information is processed in tagging core routines (right column).

Here, we concentrate on the TAGGING submodel (Fig. 1, right column). For the initialisation of the tagged tracers two options are available. First, the variables can be initialised from files, or second the tagged tracers can be initialised according to their key characteristics. In this case, the tagged stratospheric ozone is initialised by the ozone field above the tropopause and all other tagged ozone fields are zero above the tropopause and vice versa. Below the tropopause, all but the tagged stratospheric ozone tracer, obtain one-ninth of the tropospheric ozone concentration.

At each time step during the simulation, the online emissions (soil emissions) are added to the respectively tagged tracer (Table 2). The emission rate is obtained by recording the concentration of $\mathrm{NO}_{x}$ before and after the calculation of online emissions. The tagged lighting $\mathrm{NO}_{y}$ tracer obtains the same lightning emissions as the chemical NO tracer, which is provided by the lightning submodel LNOX (Tost et al., 2007; Grewe et al., 2001). Dry and wet deposition is treated as a bulk process. Changes in the concentration of all relevant chemical species are calculated in a practical and sim- 


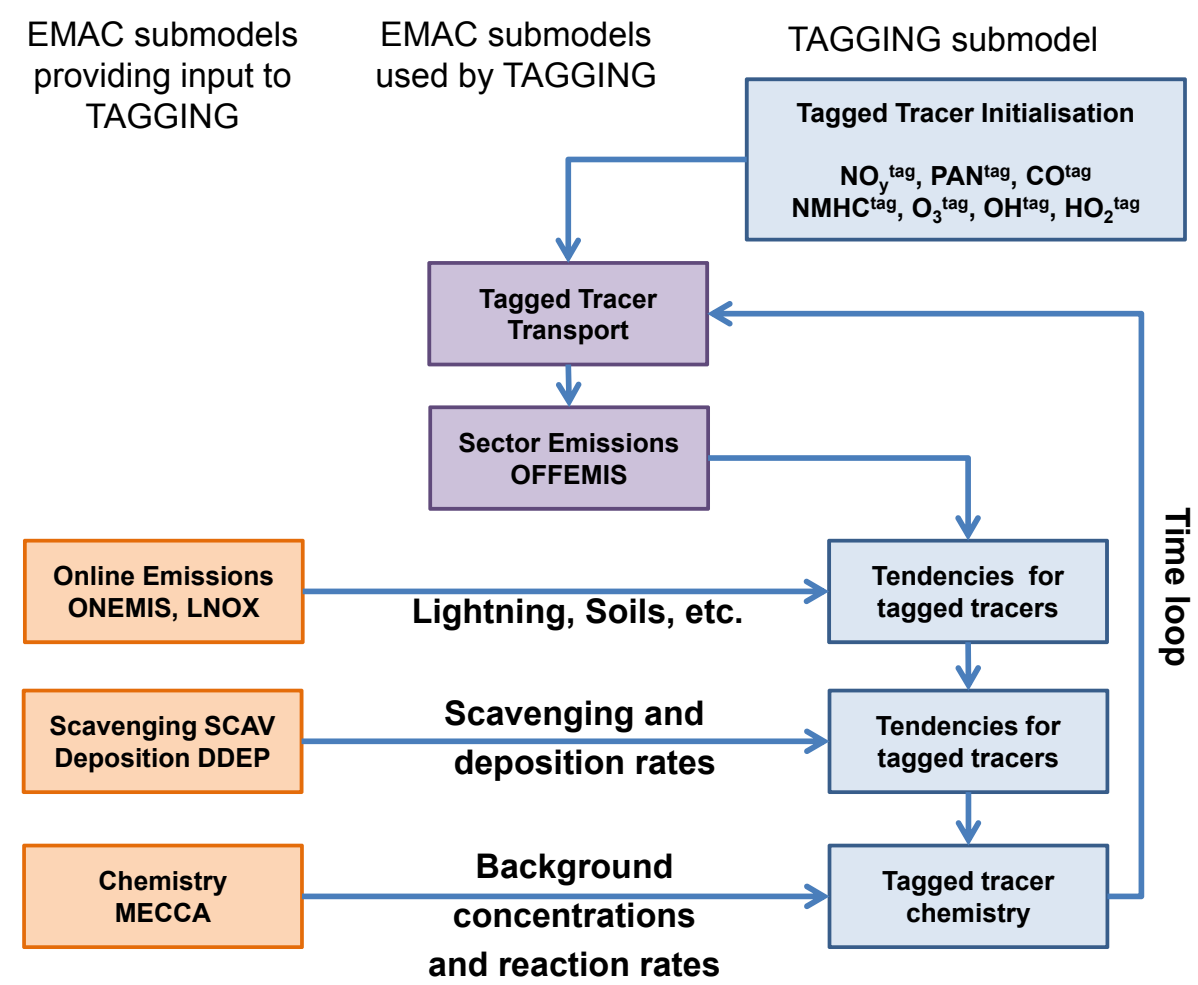

Figure 1. Sketch of the tagging algorithm.

ple manner, by the difference in the respective concentrations before and after dry and wet deposition is calculated. This tendency of the concentration is provided to the tagging submodel and distributed among the tagged species according to their relative contribution to the total concentration.

\subsection{TAGGING chemistry}

The core of the tagging submodel is the distribution of the chemical tendencies to the tagged tracers as introduced in Sect. 2. Therefore, the individual production and loss terms have to be determined adequately to calculate concentration changes via Eq. (7). Here, we consider effective ozone production and loss terms according to Crutzen and Schmaizl (1983). This implies that a family is considered for ozone (see Supplement for more details), which includes all fast exchanges between ozone and other chemical species. The ozone production basically requires splitting up an oxygen molecule. For the identification of ozone production and loss reactions, we apply the tool ProdLoss (see Supplement for more detailed information), which identifies the effective production and loss reactions for a family in the selected chemical mechanism. This family for effective ozone is hereafter referred to as ozone for simplicity. This results in two ozone production terms, which are applied to any tagged ozone field with the exception of stratospheric ozone. This is Reaction (R1) and the combination of reactions of the type (see Supplement for more detailed information)

$\mathrm{NO}+\mathrm{RO}_{2} \longrightarrow \mathrm{NO}_{2}+\mathrm{RO}$

with reaction rate $P_{\mathrm{R} 2}$. The production and loss terms of these tagged ozone fields are then

$$
\begin{aligned}
{P \mathrm{O}_{3}}^{\mathrm{tag}}= & \frac{1}{2} P_{\mathrm{R} 1}\left(\frac{\mathrm{NO}_{y}^{\mathrm{tag}}}{\mathrm{NO}_{y}}+\frac{\mathrm{HO}_{2}{ }^{\mathrm{tag}}}{\mathrm{HO}_{2}}\right) \\
& +\frac{1}{2} P_{\mathrm{R} 2}\left(\frac{\mathrm{NO}_{y}^{\mathrm{tag}}}{\mathrm{NO}_{y}}+\frac{\mathrm{NMHC}^{\mathrm{tag}}}{\mathrm{NMHC}}\right), \\
\mathrm{DO}_{3}{ }^{\mathrm{tag}}= & \frac{1}{2} P_{\mathrm{R} 3}\left(\frac{\mathrm{OH}^{\mathrm{tag}}}{\mathrm{OH}}+\frac{\mathrm{O}_{3}{ }^{\mathrm{tag}}}{\mathrm{O}_{3}}\right) \\
& +\frac{1}{2} P_{\mathrm{R} 4}\left(\frac{\mathrm{HO}_{2}{ }^{\mathrm{tag}}}{\mathrm{HO}_{2}}+\frac{\mathrm{O}_{3}{ }^{\mathrm{tag}}}{\mathrm{O}_{3}}\right) \\
& +\frac{1}{2} P_{\mathrm{R} 5}\left(\frac{\mathrm{NO}_{y}^{\mathrm{tag}}}{\mathrm{NO}_{y}}+\frac{\mathrm{O}_{3}{ }^{\mathrm{tag}}}{\mathrm{O}_{3}}\right) \\
& +\frac{1}{2} P_{\mathrm{R} 6}\left(\frac{\mathrm{NMHC}^{\mathrm{tag}}}{\mathrm{NMHC}_{3}}+\frac{\mathrm{O}_{3} \mathrm{O}_{3}}{\mathrm{O}_{3}}\right) \\
& +P_{\mathrm{R} 7} \frac{\mathrm{O}_{3}{ }^{\mathrm{tag}}}{\mathrm{O}_{3}},
\end{aligned}
$$

with "tag" denoting one of the 10 source tags and with the reaction rates $P_{\mathrm{R} 3}, P_{\mathrm{R} 4}, P_{\mathrm{R} 5}, P_{\mathrm{R} 6}, P_{\mathrm{R} 7}$ referring to the reactions 


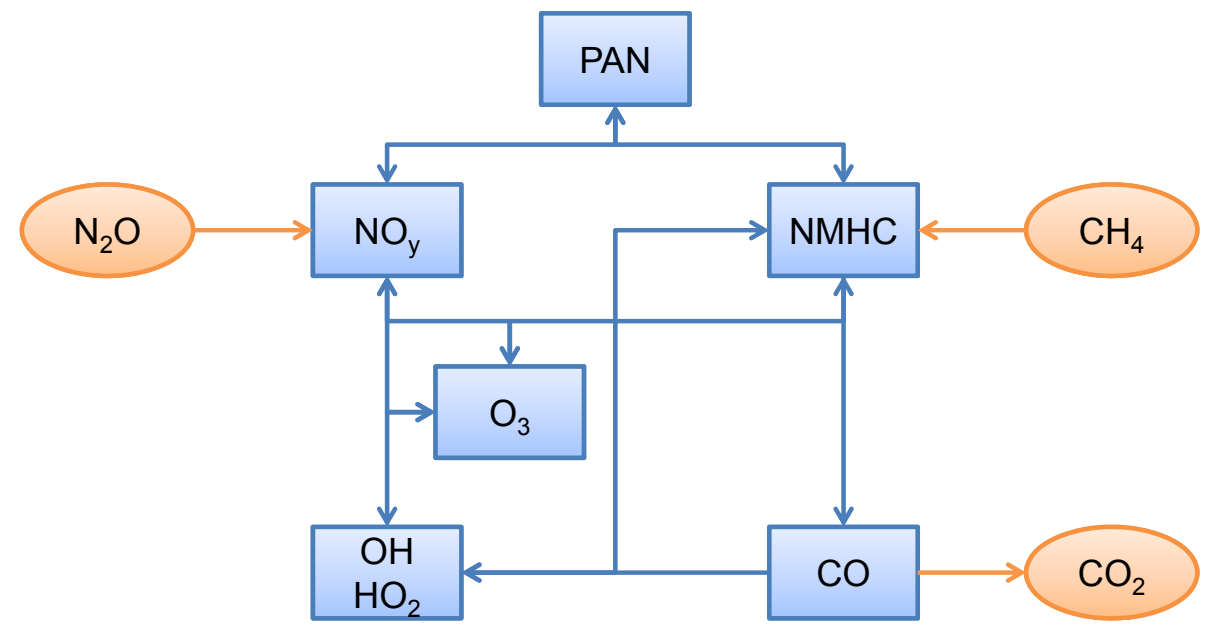

Figure 2. Sketch of the chemistry of tagged species (blue) and key relations to other species (orange). Note that stratospheric ozone is not included here. For $\mathrm{HO}_{x}$ chemistry see also Fig. 3.

$$
\begin{gathered}
\mathrm{OH}+\mathrm{O}_{3} \longrightarrow \mathrm{HO}_{2}+\mathrm{O}_{2} \\
\mathrm{HO}_{2}+\mathrm{O}_{3} \longrightarrow \mathrm{OH}+2 \mathrm{O}_{2}
\end{gathered}
$$

Effective ozone loss via $\mathrm{NO}_{y}$

$$
\begin{aligned}
\mathrm{RO}_{2}+\mathrm{O}_{3} & \longrightarrow \mathrm{RO}+2 \mathrm{O}_{2} \\
\mathrm{OH}+\mathrm{O}_{3} & \longrightarrow \mathrm{HO}_{2}+\mathrm{O}_{2}
\end{aligned}
$$

The tagged species $\mathrm{NO}_{y}, \mathrm{CO}, \mathrm{NMHC}$, and PAN are treated similarly and will be discussed here only briefly, while more detailed information is provided in the supplement. Figure 2 sketches the principal relations between the tagged species. Methane (not tagged) is depleted and the chemical products are then tagged as "NMHC from methane". The species in the NMHC family are eventually transformed into $\mathrm{CO}$ and further into $\mathrm{CO}_{2}$. The decomposition of $\mathrm{N}_{2} \mathrm{O}$ (not tagged) constitutes a source for "stratospheric $\mathrm{NO}_{y}$ ". Reactions between $\mathrm{NO}_{y}$ and NMHCs form PAN (not included in $\mathrm{NO}_{y}$ ). PAN is an important species, which can be transported over long distances before it thermally decomposes (Roberts, 2007).

$\mathrm{HO}_{x}$ chemistry (Fig. 3 and Table 3 ) and the calculation of the individual contributions to the concentrations of $\mathrm{OH}$ and $\mathrm{HO}_{2}$ is much more complex; hence, we discuss it here in more detail. The main source of $\mathrm{OH}$ is the reaction of $\mathrm{H}_{2} \mathrm{O}$ with $\mathrm{O}\left({ }^{1} \mathrm{D}\right)$. The chemical reactions between $\mathrm{OH}$ and $\mathrm{HO}_{2}$ involve species such as $\mathrm{CO}, \mathrm{CH}_{4}, \mathrm{NO}_{y}$, and NMHC. Losses of $\mathrm{HO}_{x}$ are the formation of $\mathrm{H}_{2} \mathrm{O}_{2}$ and $\mathrm{HNO}_{3}$, which are soluble and can be easily rained out.

Since the lifetime of both $\mathrm{OH}$ and $\mathrm{HO}_{2}$ is short, we assume steady state for the contributions. We refer to the main $\mathrm{HO}_{x}$ reactions, for which the production and loss rates are calculated in and provided by the MECCA submodel (see also Table 2).
The steady-state assumption for the contributions to the $\mathrm{OH}$ and $\mathrm{HO}_{2}$ concentrations, i.e. $\mathrm{OH}^{\text {tag }}$ and $\mathrm{HO}_{2}^{\text {tag }}$, implies that the individual production terms equal the individual loss terms:

$$
\begin{aligned}
P_{\mathrm{OH}}^{\mathrm{tag}} & =L_{\mathrm{OH}}^{\mathrm{tag}}, \\
P_{\mathrm{HO}_{2}}^{\mathrm{tag}} & =L_{\mathrm{HO}_{2}}^{\mathrm{tag}} .
\end{aligned}
$$

Again the more complex part of the tagging chemistry is to derive the production and loss terms. Using the reactions in Table 3 and the approach from Grewe et al. (2010), we obtain for the production and loss of $\mathrm{OH}^{\text {tag. }}$ :

$$
\begin{aligned}
P_{\mathrm{OH}}^{\mathrm{tag}}= & P_{1}^{\mathrm{OH}} \frac{\mathrm{O}_{3}{ }^{\mathrm{tag}}}{\mathrm{O}_{3}}+\frac{1}{2} P_{2}^{\mathrm{OH}}\left(\frac{\mathrm{HO}_{2}{ }^{\mathrm{tag}}}{\mathrm{HO}_{2}}+\frac{\mathrm{O}_{3}{ }^{\mathrm{tag}}}{\mathrm{O}_{3}}\right) \\
& +\frac{1}{2} P_{3}^{\mathrm{OH}}\left(\frac{\mathrm{NO}_{y}^{\mathrm{tag}}}{\mathrm{NO}_{y}}+\frac{\mathrm{HO}_{2}{ }^{\mathrm{tag}}}{\mathrm{HO}_{2}}\right) \\
L_{\mathrm{OH}}^{\mathrm{tag}}= & L_{1}^{\mathrm{OH}} \frac{1}{2}\left(\frac{\mathrm{OH}^{\mathrm{tag}}}{\mathrm{OH}}+\frac{\mathrm{CO}^{\mathrm{tag}}}{\mathrm{CO}}\right) \\
& +L_{2}^{\mathrm{OH}}\left(\frac{\mathrm{OH}^{\mathrm{tag}}}{\mathrm{OH}}\right) \\
& +L_{3}^{\mathrm{OH}} \frac{1}{2}\left(\frac{\mathrm{OH}^{\mathrm{tag}}}{\mathrm{OH}}+\frac{\mathrm{O}_{3}{ }^{\mathrm{tag}}}{\mathrm{O}_{3}}\right) \\
& +L_{4}^{\mathrm{OH}} \frac{1}{2}\left(\frac{\mathrm{OH}^{\mathrm{tag}}}{\mathrm{OH}}+\frac{\mathrm{NMHC}^{\mathrm{tag}}}{\mathrm{NMHC}^{\mathrm{H}}}\right) \\
& +L_{5}^{\mathrm{OH}} \frac{1}{2}\left(\frac{\mathrm{OH}^{\mathrm{tag}}}{\mathrm{OH}}+\frac{\mathrm{HO}_{2}{ }^{\mathrm{tag}}}{\mathrm{HO}_{2}}\right) \\
& +L_{6}^{\mathrm{OH}} \frac{1}{2}\left(\frac{\mathrm{OH}^{\mathrm{tag}}}{\mathrm{OH}}+\frac{\mathrm{NO}_{y}^{\mathrm{tag}}}{\mathrm{NO}_{y}}\right) .
\end{aligned}
$$




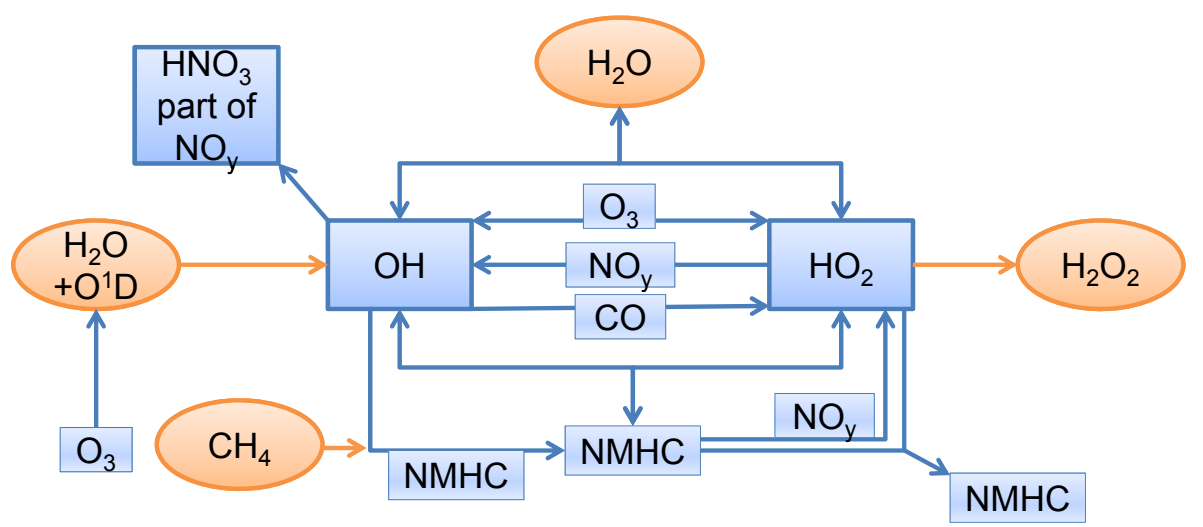

Figure 3. Atmospheric $\mathrm{HO}_{x}$ chemistry used in the TAGGING scheme. Blue boxes indicate tagged species and families and orange circles non-tagged species. Arrows indicate reactions.

Table 3. Reactions and reaction rates used for the calculation of $\mathrm{OH}$ and $\mathrm{HO}_{2}$ contributions.

\begin{tabular}{|c|c|c|c|c|c|c|}
\hline \multirow{3}{*}{ Reaction } & & & \multicolumn{4}{|c|}{ Reaction rate } \\
\hline & & & \multicolumn{2}{|c|}{$\mathrm{OH}$} & \multicolumn{2}{|c|}{$\mathrm{HO}_{2}$} \\
\hline & & & Prod & Loss & Prod & Loss \\
\hline $\mathrm{H}_{2} \mathrm{O}+\mathrm{O}\left({ }^{1} \mathrm{D}\right)$ & $\longrightarrow$ & $2 \mathrm{OH}$ & $0.5 P_{1}^{\mathrm{OH}}$ & & & \\
\hline $\mathrm{HO}_{2}+\mathrm{O}_{3}$ & $\longrightarrow$ & $\mathrm{OH}+2 \mathrm{O}_{2}$ & $P_{2}^{\mathrm{OH}}$ & & & $L_{1}^{\mathrm{HO}_{2}}$ \\
\hline $\mathrm{NO}+\mathrm{HO}_{2}$ & $\longrightarrow$ & $\mathrm{NO}_{2}+\mathrm{OH}$ & $P_{3}^{\mathrm{OH}}$ & & & $L_{2}^{\mathrm{HO}_{2}}$ \\
\hline $\mathrm{OH}+\mathrm{CO}$ & $\stackrel{\mathrm{O}_{2}}{\longrightarrow}$ & $\mathrm{HO}_{2}+\mathrm{CO}_{2}$ & & $L_{1}^{\mathrm{OH}}$ & $P_{1}^{\mathrm{HO}_{2}}$ & \\
\hline $\mathrm{OH}+\mathrm{CH}_{4}$ & $\stackrel{\mathrm{O}_{2}}{\longrightarrow}$ & $\mathrm{NMHC}+\mathrm{H}_{2} \mathrm{O}$ & & $L_{2}^{\mathrm{OH}}$ & & \\
\hline $\mathrm{OH}+\mathrm{O}_{3}$ & $\longrightarrow$ & $\mathrm{HO}_{2}+\mathrm{O}_{2}$ & & $L_{3}^{\mathrm{OH}}$ & $P_{2}^{\mathrm{HO}_{2}}$ & \\
\hline $\mathrm{OH}+\mathrm{NMHC}$ & $\stackrel{\mathrm{O}_{2}}{\longrightarrow}$ & $\mathrm{NMHC}+\mathrm{H}_{2} \mathrm{O}$ & & $L_{4}^{\mathrm{OH}}$ & & \\
\hline $\mathrm{OH}+\mathrm{HO}_{2}$ & $\longrightarrow$ & $\mathrm{H}_{2} \mathrm{O}+\mathrm{O}_{2}$ & & $L_{5}^{\mathrm{OH}}$ & & $L_{3}^{\mathrm{HO}_{2}}$ \\
\hline $\mathrm{OH}+\mathrm{NO}_{2}$ & $\longrightarrow$ & $\mathrm{HNO}_{3}$ & & $L_{6}^{\mathrm{OH}}$ & & \\
\hline $\mathrm{NMHC}+\mathrm{NO}$ & $\longrightarrow$ & $\mathrm{NMHC}+\mathrm{HO}_{2}+\mathrm{NO}_{2}$ & & & $P_{3}^{\mathrm{HO}_{2}}$ & \\
\hline $\mathrm{NMHC}+\mathrm{HO}_{2}$ & $\longrightarrow$ & $\mathrm{NMHC}+\mathrm{O}_{2}$ & & & & $L_{4}^{\mathrm{HO}_{2}}$ \\
\hline $\mathrm{HO}_{2}+\mathrm{HO}_{2}$ & $\longrightarrow$ & $\mathrm{H}_{2} \mathrm{O}_{2}+\mathrm{O}_{2}$ & & & & $L_{5}^{\mathrm{HO}_{2}}$ \\
\hline
\end{tabular}

This set of equations includes the assumption that exchanges within a family are fast enough to achieve equally distributed tags among family members. For example, concerning $P_{1}^{\mathrm{OH}}$, the contribution of one source to $\mathrm{O}\left({ }^{1} \mathrm{D}\right)$ equals that of $\mathrm{O}_{3}$, i.e. $\frac{O\left({ }^{1} \mathrm{D}\right)^{\mathrm{tag}}}{O\left({ }^{1} \mathrm{D}\right)}=\frac{\mathrm{O}_{3}{ }^{\mathrm{tag}}}{\mathrm{O}_{3}}$.

Similarly, we derive the individual production and loss terms for $\mathrm{HO}_{2}$ :

$P_{\mathrm{HO}_{2}}^{\mathrm{tag}}=P_{1}^{\mathrm{HO}_{2}} \frac{1}{2}\left(\frac{\mathrm{OH}^{\mathrm{tag}}}{\mathrm{OH}}+\frac{\mathrm{CO}^{\mathrm{tag}}}{\mathrm{CO}}\right)$

$$
\begin{aligned}
& +P_{2}^{\mathrm{HO}_{2}} \frac{1}{2}\left(\frac{\mathrm{OH}^{\mathrm{tag}}}{\mathrm{OH}}+\frac{\mathrm{O}_{3}^{\mathrm{tag}}}{\mathrm{O}_{3}}\right) \\
& +P_{3}^{\mathrm{HO}_{2}} \frac{1}{2}\left(\frac{\mathrm{NMHC}^{\mathrm{tag}}}{\mathrm{NMHC}}+\frac{\mathrm{NO}_{y}^{\mathrm{tag}}}{\mathrm{NO}_{y}}\right),
\end{aligned}
$$

$$
\begin{aligned}
L_{\mathrm{HO}_{2}}^{\mathrm{tag}}= & L_{1}^{\mathrm{HO}_{2}} \frac{1}{2}\left(\frac{\mathrm{HO}_{2}{ }^{\mathrm{tag}}}{\mathrm{HO}_{2}}+\frac{\mathrm{O}_{3}{ }^{\mathrm{tag}}}{\mathrm{O}_{3}}\right) \\
& +L_{2}^{\mathrm{HO}_{2}} \frac{1}{2}\left(\frac{\mathrm{HO}_{2}{ }^{\mathrm{tag}}}{\mathrm{HO}_{2}}+\frac{\mathrm{NO}_{y}^{\mathrm{tag}}}{\mathrm{NO}_{y}}\right)
\end{aligned}
$$




$$
\begin{aligned}
& +L_{3}^{\mathrm{HO}_{2}} \frac{1}{2}\left(\frac{\mathrm{HO}_{2}{ }^{\mathrm{tag}}}{\mathrm{HO}_{2}}+\frac{\mathrm{OH}^{\mathrm{tag}}}{\mathrm{OH}}\right) \\
& +L_{4}^{\mathrm{HO}_{2}} \frac{1}{2}\left(\frac{\mathrm{HO}_{2}{ }^{\mathrm{tag}}}{\mathrm{HO}_{2}}+\frac{\mathrm{NMHC}^{\mathrm{tag}}}{\mathrm{NMHC}}\right) \\
& +L_{5}^{\mathrm{HO}_{2}} \frac{\mathrm{HO}_{2}{ }^{\mathrm{tag}}}{\mathrm{HO}_{2}} .
\end{aligned}
$$

Now the Eqs. (15) and (16) can be written as

$$
\begin{aligned}
& 0=A^{\text {tag }}-L^{\mathrm{OH}} \frac{\mathrm{OH}^{\mathrm{tag}}}{\mathrm{OH}}+P^{\mathrm{OH}} \frac{\mathrm{HO}_{2}{ }^{\mathrm{tag}}}{\mathrm{HO}_{2}}, \\
& 0=B^{\mathrm{tag}}+P^{\mathrm{HO}_{2}} \frac{\mathrm{OH}^{\mathrm{tag}}}{\mathrm{OH}}-L^{\mathrm{HO}_{2}} \frac{\mathrm{HO}_{2}{ }^{\mathrm{tag}}}{\mathrm{HO}_{2}},
\end{aligned}
$$

with

$$
\begin{aligned}
& A^{\mathrm{tag}}=P_{1}^{\mathrm{OH}} \frac{\mathrm{O}_{3}{ }^{\mathrm{tag}}}{\mathrm{O}_{3}}+\frac{1}{2} P_{2}^{\mathrm{OH}} \frac{\mathrm{O}_{3}{ }^{\mathrm{tag}}}{\mathrm{O}_{3}} \\
& +\frac{1}{2} P_{3} \frac{\mathrm{OH}_{y}^{\mathrm{tag}}}{\mathrm{NO}_{y}} \\
& -\frac{1}{2} L_{1}^{\mathrm{OH}} \frac{\mathrm{CO}^{\mathrm{tag}}}{\mathrm{CO}}-\frac{1}{2} L_{3}^{\mathrm{OH}_{3}} \frac{\mathrm{O}_{3}{ }^{\mathrm{tag}}}{\mathrm{O}_{3}} \\
& -\frac{1}{2} L_{4}^{\mathrm{OH}} \frac{\mathrm{NMHC}^{\mathrm{tag}}}{\mathrm{NMHC}}-\frac{1}{2} L_{6}^{\mathrm{OH}} \frac{\mathrm{NO}_{y}^{\mathrm{tag}}}{\mathrm{NO}_{y}}, \\
& B^{\mathrm{tag}}=\frac{1}{2} P_{1}^{\mathrm{HO}_{2}} \frac{\mathrm{CO}^{\mathrm{tag}}}{\mathrm{CO}}+\frac{1}{2} P_{2}^{\mathrm{HO}_{2}} \frac{\mathrm{O}_{3}{ }^{\mathrm{tag}}}{\mathrm{O}_{3}} \\
& +\frac{1}{2} P_{3}^{\mathrm{HO}_{2}} \frac{\mathrm{NMHC}^{\mathrm{tag}}}{\mathrm{NMHC}}+\frac{1}{2} P_{3}^{\mathrm{HO}_{2}} \frac{\mathrm{NO}_{y}^{\mathrm{tag}}}{\mathrm{NO}_{y}} \\
& -\frac{1}{2} L_{1}^{\mathrm{HO}_{2}} \frac{\mathrm{O}_{3}{ }^{\mathrm{tag}}}{\mathrm{O}_{3}}-\frac{1}{2} L_{2}^{\mathrm{HO}_{2}} \frac{\mathrm{NO}_{y}^{\mathrm{tag}}}{\mathrm{NO}_{y}} \\
& -\frac{1}{2} L_{4}^{\mathrm{HO}_{2}} \frac{\mathrm{NMHC}^{\mathrm{tag}}}{\mathrm{NMHC}}, \\
& P^{\mathrm{OH}}=\frac{1}{2}\left(P_{2}^{\mathrm{OH}}+P_{3}^{\mathrm{OH}}-L_{5}^{\mathrm{OH}}\right), \\
& L^{\mathrm{OH}}=\frac{1}{2}\left(L_{1}^{\mathrm{OH}}+2 L_{2}^{\mathrm{OH}}+L_{3}^{\mathrm{OH}}\right. \\
& \left.+L_{4}^{\mathrm{OH}}+L_{5}^{\mathrm{OH}}+L_{6}^{\mathrm{OH}}\right) \text {, } \\
& P^{\mathrm{HO}_{2}}=\frac{1}{2}\left(P_{1}^{\mathrm{HO}_{2}}+P_{2}^{\mathrm{HO}_{2}}\right), \\
& L^{\mathrm{HO}_{2}}=\frac{1}{2}\left(L_{1}^{\mathrm{HO}_{2}}+L_{2}^{\mathrm{HO}_{2}}+L_{3}^{\mathrm{HO}_{2}}\right. \\
& \left.+L_{4}^{\mathrm{HO}_{2}}+2 L_{5}^{\mathrm{HO}_{2}}\right) \text {. }
\end{aligned}
$$

The Eqs. (21) and (22) can easily be solved resulting in

$$
\begin{aligned}
\mathrm{OH}^{\mathrm{tag}} & =\frac{A^{\mathrm{tag}} L^{\mathrm{HO}_{2}}+B^{\mathrm{tag}} P^{\mathrm{OH}}}{L^{\mathrm{OH}} L^{\mathrm{HO}_{2}}-P^{\mathrm{OH}} P^{\mathrm{HO}}{ }_{2}} \mathrm{OH}, \\
\mathrm{HO}_{2}{ }^{\mathrm{tag}} & =\frac{A^{\mathrm{tag}} P^{\mathrm{HO}_{2}}+B^{\mathrm{tag}} L^{\mathrm{OH}}}{L^{\mathrm{OH}} L^{\mathrm{HO}_{2}}-P^{\mathrm{OH}} P^{\mathrm{HO}_{2}}} \mathrm{HO}_{2} .
\end{aligned}
$$

The quantity $A^{\text {tag }}\left(B^{\text {tag }}\right)$ represents the contribution of chemical tracers (tagged and non-tagged, other than $\mathrm{OH}$ and
$\mathrm{HO}_{2}$ ) to the net $\mathrm{OH}$ production (net $\mathrm{HO}_{2}$ production). The terms $L^{\mathrm{OH}}$ and $P^{\mathrm{OH}}$ are primarily contributions to $\mathrm{OH}$ loss and production rates, which depend on the contribution to $\mathrm{OH}\left(\mathrm{OH}^{\mathrm{tag}}\right)$ and $\mathrm{HO}_{2}\left(\mathrm{HO}_{2}{ }^{\mathrm{tag}}\right)$, respectively. Only the reaction of $\mathrm{OH}$ with $\mathrm{HO}_{2}$ forming water vapour and molecular oxygen constitutes an exception, since the loss of $\mathrm{OH}$ is dependent on both $\mathrm{OH}$ and $\mathrm{HO}_{2}\left(L_{5}^{\mathrm{OH}}\right)$. Therefore, it also contributes to $P^{\mathrm{OH}}$ (see Eq. 25), the last term in Eq. (21), which depends on $\mathrm{HO}_{2}$. Note that in this case it does not lead to a production but destruction of $\mathrm{OH}$.

\section{Present-day simulation and comparison to other studies}

In this section, we present results of a present-day simulation. An actual validation of the tagging method is not feasible, since only the full quantities can be measured, e.g. the ozone concentration, but not the contribution from individual sources. Therefore, we concentrate on a comparison to earlier studies. In the following sections we present the simulation set-up and give a plausibility check for contributions to the $\mathrm{HO}_{x}$ concentration based on shipping and aviation, focussing on the ozone concentration.

\subsection{Simulation set-ups}

\subsubsection{EMAC}

To evaluate the TAGGING submodel, we conduct two different simulations, one base simulation with all emissions and a second simulation where we reduced all road traffic emissions by five percent. The set-up follows the "Specified Dynamics Reference Simulation" for the Chemistry Climate Model Initiative, and is identical to the RC1SD-base10a setup described and evaluated by Jöckel et al. (2016), however, extended by the TAGGING module, which we described above.

The simulation is performed with a spectral resolution of T42 and a vertical resolution of 90 levels (up to $0.01 \mathrm{hPa}$ ). For the anthropogenic emissions we use the MACCity emissions dataset with a resolution of $0.5^{\circ}$ described by Granier et al. (2011). The lightning emissions are calculated online using the parameterisation described by Grewe et al. (2001). Emissions of NO from soil and biogenic origin as well as biogenic isoprene $\left(\mathrm{C}_{5} \mathrm{H}_{8}\right)$ are calculated online by the MESSy submodel ONEMIS (described as ONLEM in Kerkweg et al., 2006b). The submodel ONEMIS uses an algorithm based on Yienger and Levy (1995) for NO and Guenther et al. (1995) for isoprene. The dynamic state of the atmosphere is relaxed towards ERA-Interim reanalysis data (Dee et al., 2011) using a weak Newtonian relaxation ("nudging") of the four prognostic variables temperature, divergence, vorticity, and the logarithm of surface pressure (Jöckel et al., 2006). Seasurface temperature and sea-ice concentration are taken from ERA-Interim as well. 

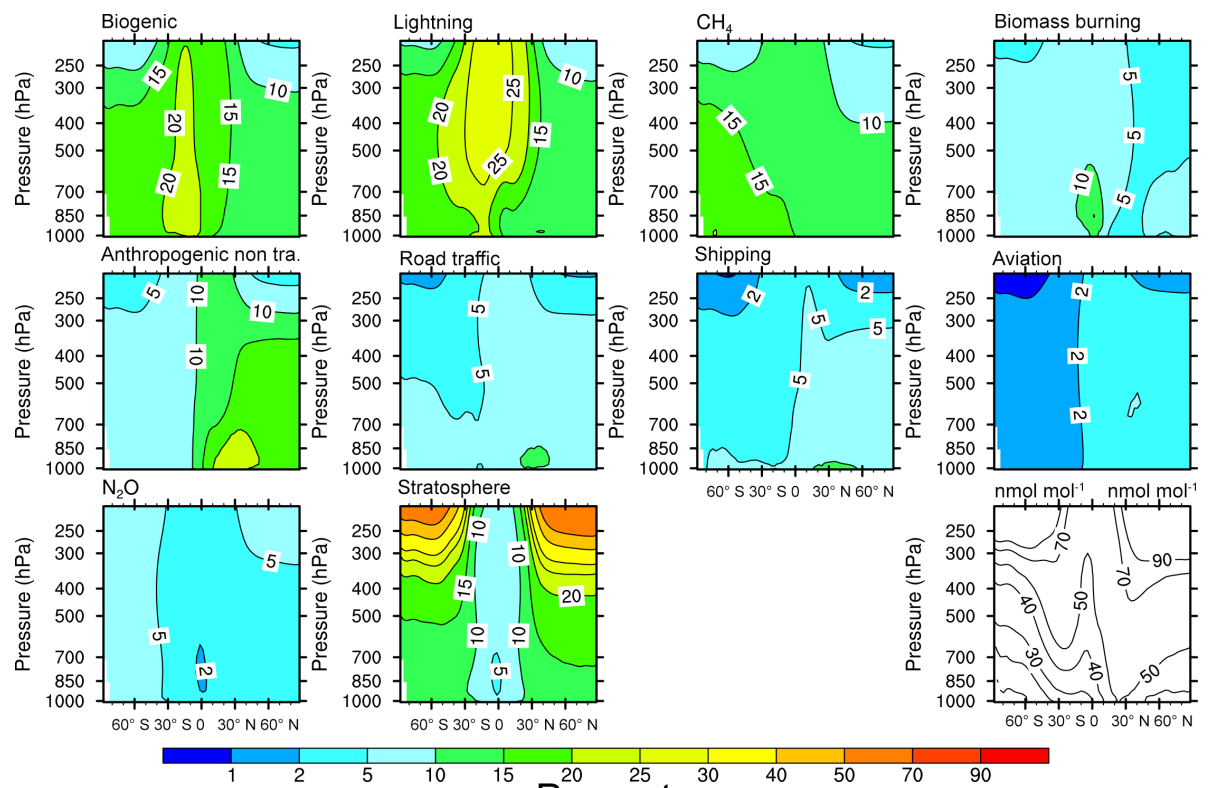

Figure 4. Annual mean contributions [\%] of 10 emission sectors to the simulated ozone volume mixing ratios. The simulated ozone volume mixing ratio is shown in the lower right panel.

One important difference of our simulation to the RC1SDbase10a set-up is the use of the QCTM mode of EMAC (Deckert et al., 2011). This QCTM mode decouples the chemistry and the dynamics by using monthly climatologies (here derived from the RC1SD-base10a simulation) in the radiation code and for the heterogeneous stratospheric reactions. The application of the QCTM mode is important for overcoming the problem of a low signal to noise ratio in the case of a direct comparison of a base case simulation with one, with a small chemical perturbation, which would be present with a fully coupled system. The dynamical and chemical differences between the RC1SD-base10a and our base simulation are shown in the Supplement. The simulation covers the period 2004-2010 and is initialised from the RC1SD-base10a simulation. The first year was used as a spin-up period, resulting in an evaluation period from 2005 to 2010 .

\subsection{2 $\operatorname{MECO}(n)$}

The COSMO/MESSy simulation shown in Sect. 5.1 covers the European domain, including parts of the eastern Atlantic and North Africa, with a resolution of $0.44^{\circ}(\approx 50 \mathrm{~km})$. Simulated is the period from July 2007 until December 2008, with the 6 months of 2007 used as spin-up phase. The driving EMAC model is applied at a resolution of T42 with 31 horizontal levels and is relaxed towards ERA-Interim reanalysis as well. The same QCTM mode as described above is applied for EMAC and COSMO/MESSy. Both model instances use the anthropogenic MACCity emissions, as well as online calculated soil/biogenic emissions as described above. The simulation differs, however, from the EMAC simulation described above, by using the lightning parameterisation after Price and Rind (1992) to simulate the lightning $\mathrm{NO}_{x}$ emissions on the global scale. In COSMO/MESSy we use the same emissions as on the global scale by regridding the corresponding emissions from EMAC. We have chosen this approach to have emissions as comparable as possible in both model instances. More detailed information about this simulation, including an evaluation of chemical tracer concentrations, is provided by Mertens et al. (2016).

\subsection{Contributions of emission sectors to $\mathrm{NO}_{y}, \mathrm{CO}$, NMHCs, and $\mathrm{O}_{3}$}

The 6-year annual average contributions of the 10 emission sectors to the ozone concentration are shown in Fig. 4. We compare these results with an earlier model version, which only tags $\mathrm{NO}_{y}$ and ozone (Grewe, 2007, Fig. 5b therein), and to earlier similar studies by Lelieveld and Dentener (2000) and Emmons et al. (2012). This comparison aims at verifying that the implementation of the TAGGING mechanism is correct by comparing contribution patterns and magnitudes. We have to keep in mind that the approach is conceptually different from earlier studies and takes into account all ozone precursor emissions and not only $\mathrm{NO}_{y}$. Hence, the individual contributions have to be smaller and no agreement can be expected, except for pattern and magnitude. The only direct intercomparison can be performed for the stratospheric ozone mixed into the troposphere, since this process is independent from any precursors. Here Lelieveld and Dentener (2000), Lamarque et al. (2005), 
Table 4. Comparison of different studies with respect to the contribution (\%) of stratospheric ozone to the tropospheric ozone concentration. Numbers are rough estimates only, as taken from published figures. Note that values for L05 are surface values only and percentage values from E12 are estimated from mixing ratios; however, a mean value of $17 \%$ is given therein. See text for more explanations. SH and NH are abbreviations for the Southern and Northern Hemispheres, respectively.

\begin{tabular}{lrrr}
\hline Reference & SH & Tropics & NH \\
\hline LD00 & 40 & 10 & 25 \\
L05 & 20 & $<10$ & 10 \\
G07 & $5-10$ & 10 & 15 \\
E12 & 20 & $<5$ & 15 \\
This work & $10-15$ & $5-10$ & $10-20$ \\
\hline
\end{tabular}

Grewe (2007), and Emmons et al. (2012) (hereafter denoted as LD00, L05, G07, and E12, respectively) estimated a 5$40 \%$ contribution from stratospheric ozone to tropospheric ozone in the Southern Hemisphere and mostly systematically lower values of $10-25 \%$ in the Northern Hemisphere, while tropical values are below $10 \%$ (Table 4). Our simulation also shows a minimum of the stratospheric ozone mixing ratios in the tropics and lower mixing ratios in the Southern Hemisphere compared to the Northern Hemisphere. The mixing ratios for January and July are very similar to those of Emmons et al. (2012, not shown).

Ozone formed from lightning $\mathrm{NO}_{x}$ (Fig. 4) shows a maximum in the tropics and upper troposphere and larger contributions in the Southern Hemisphere than in the Northern Hemisphere, which is in agreement with G07 and LD00. The maximum contribution from lightning is around 25$30 \%$ and thus lower than G07 (40\%) and LD00 (50\%), because here we regard the ozone production of all precursors, whereas in G07 and LD00 only $\mathrm{NO}_{x}$ as a precursor is considered (see above).

Agreement between the studies LD00, G07, E12, and our work can also be found with respect to the contribution of anthropogenic emissions to tropospheric ozone. These emissions (here: anthropogenic non-traffic, road traffic, shipping, and aviation) predominantly contribute by $30-50 \%$ in the Northern Hemisphere. The ozone contribution from biomass burning peaks in the lower tropical troposphere with values of around 10-15\%, which compares well with G07 and LD00 (20\%). Around $15 \%$ of the tropospheric ozone originates from methane, which reacts with $\mathrm{OH}$ and contributes to $\mathrm{NMHC}$ compounds and eventually to $\mathrm{CO}$ and $\mathrm{CO}_{2}$.

Figure 5 shows the contribution of the individual emission sectors to the tropospheric budgets of $\mathrm{NO}_{y}, \mathrm{CO}, \mathrm{NMHC}$, $\mathrm{PAN}$, and $\mathrm{O}_{3}$. Lightning and non-traffic anthropogenic emissions show the largest contributions to $\mathrm{NO}_{y}$. The emitted $\mathrm{NO}_{y}$ from lightning and aviation remains much longer in the atmosphere compared to a surface source, such as non-traffic anthropogenic $\mathrm{NO}_{y}$, since lightning and aviation emit mainly in the upper troposphere. Aviation, shipping, and biomass burning have approximately the same contribution.

The different emission sectors have very different emission characteristics. Some are only emitting $\mathrm{NO}_{y}$, such as lightning, or $\mathrm{NO}_{y}$ and NMHCs, such as most anthropogenic sources. This is well reflected in the budgets (Fig. 5). Since $\mathrm{NO}_{y}$ is required to form PAN, the decomposition of PAN also produces $\mathrm{NO}_{y}$ and NMHCs with the original tag, e.g. the lightning tag. This is fully consistent with the chosen tagging approach and leads to minor contributions of non-CO and non-NMHC emitting emission sectors to the $\mathrm{CO}$ and NMHC budgets (lightning, stratosphere, aviation). For example, $\mathrm{NO}_{x}$ emitted by road traffic may react with hydrocarbons from, e.g., biogenic emissions to form PAN, which is then transported over longer distances. When decomposed after being transported over a long distance, the products obtain tags from both sources. Hence, hydrocarbons, which may not have been emitted by road traffic, obtain in this process a road traffic tag. The reasoning behind this is that only the PAN formation allowed for the long-range transport of either species and hence both emission sources have affected this. While this case is a wanted tagging effect, other situations may lead to unwanted side effects or even unphysical effects (see discussion in Sect. 6 for more details). The formation of PAN and hence contributions to PAN (Fig. 5, second row) requires both $\mathrm{NO}_{y}$ and NMHCs. None of the 10 emission sectors has a large contribution from both; hence, the contributions of each of the 10 sectors to PAN are almost equally distributed around $10 \%$. One exception is methane, which contributes largely to NMHC concentrations but not to $\mathrm{NO}_{y}$. In addition, the NMHCs from methane are predominantly occurring in areas with low $\mathrm{NO}_{y}$ background, which reduces the impact on PAN. The contribution to tropospheric ozone (Fig. 5, second row) reflects the distribution presented in Fig. 4, with major contributions from lightning, stratosphere, anthropogenic non-traffic emissions, and methane.

\subsection{Contribution of emission sectors to $\mathrm{HO}_{x}$ concentrations}

In this section, we present the effects of a surface source (shipping) and a higher-altitude atmospheric source (aviation) on their contribution to the $\mathrm{HO}_{x}$ concentrations. We have chosen the Mediterranean Sea for shipping, since it includes areas in the middle of the Sea on the one hand, as well as areas that are largely affected by other sources, e.g. in southern France (Marseilles) and Italy (harbour areas such as Genoa, Fig. 6), on the other hand.

We have identified four areas (A-D) with different chemical characteristics (Table 5, see also Fig. 6): highly polluted areas with high concentrations of $\mathrm{NO}_{2}(\mathrm{~A}$ and $\mathrm{B})$ and with a large (some) impact from shipping in region $\mathrm{A}$ (B); a more remote area with some impact from shipping on $\mathrm{NO}_{x}$ and $\mathrm{O}_{3}$ (C), and a more remote area with a larger values of shipping ozone (D). 

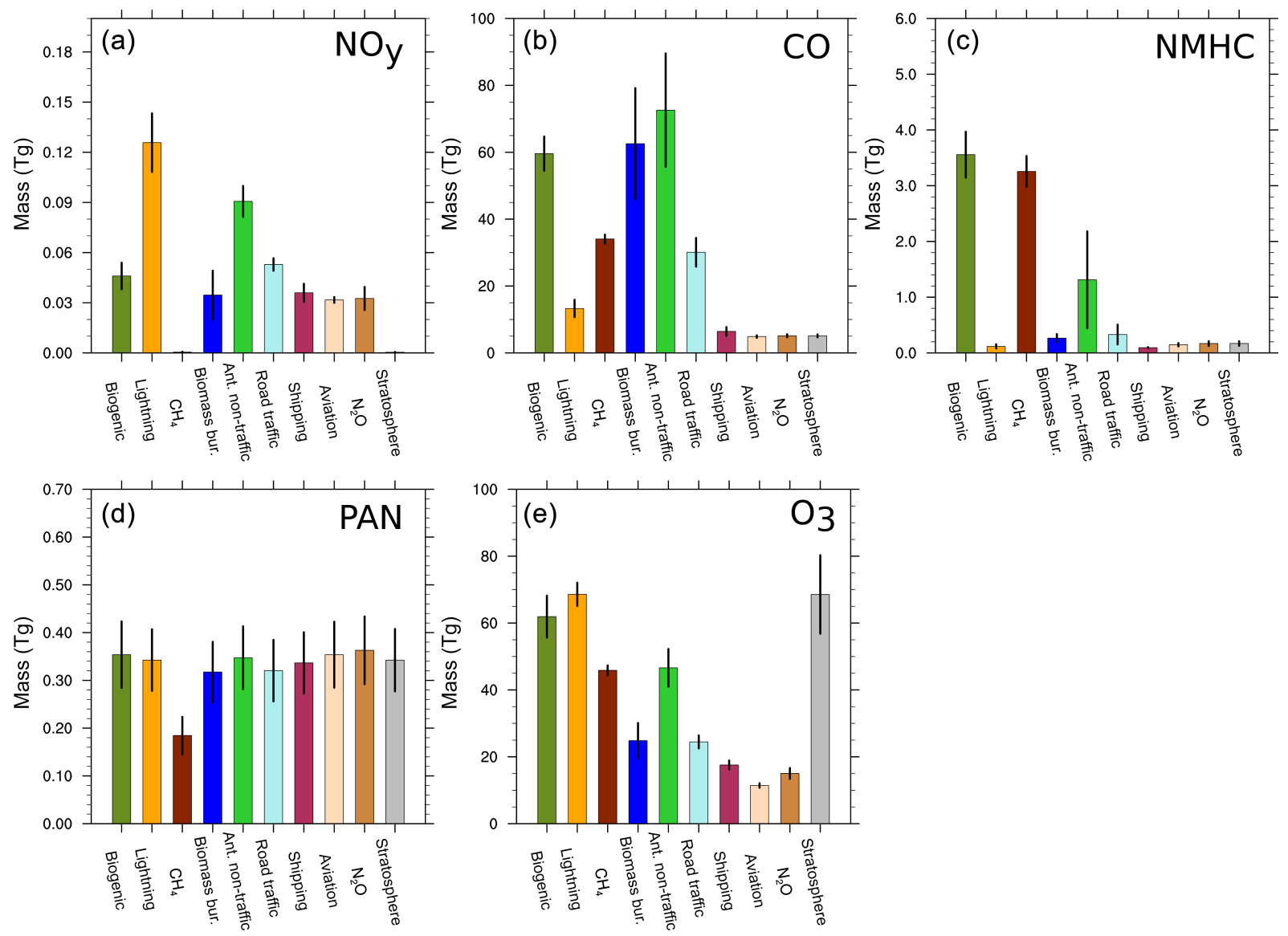

Figure 5. Contributions to the annual mean tropospheric budgets [Tg] of 10 emission sectors. (a-c) $\mathrm{NO}_{y}$, CO, and NMHCs; (d, e) PAN and $\mathrm{O}_{3}$. Error bars indicate the interannual variability.

Table 5. Qualitative characterisation of four different regions (A-D) in the Mediterranean Sea. A: southern France; B: Strait of Gibraltar; C: central Mediterranean Sea; D: Tunesian coast. See Fig. 6 (top row) for the location of the regions. The signs "++", “+”, "0”, and "-"” indicate a qualitative estimate of the respective characteristics, "very strong/very large", "strong/large", "moderate", "negative".

\begin{tabular}{|c|c|c|c|c|}
\hline & A & $\mathrm{B}$ & $\mathrm{C}$ & $\mathrm{D}$ \\
\hline Region has polluted background & ++ & + & $\circ$ & $\circ$ \\
\hline Region is impacted by shipping $\mathrm{NO}_{x}$ & ++ & + & + & ++ \\
\hline Region is impacted by shipping ozone & + & + & + & ++ \\
\hline Shipping emissions are converting $\mathrm{HO}_{2}$ into $\mathrm{OH}$ via $\mathrm{NO}+\mathrm{HO}_{2} \longrightarrow \mathrm{OH}+\mathrm{NO}_{2}$ & ++ & ++ & + & + \\
\hline Shipping ozone produces $\mathrm{OH}$ via $\mathrm{O}_{3} \longrightarrow \mathrm{O}\left({ }^{1} \mathrm{D}\right) \stackrel{\mathrm{H}_{2} \mathrm{O}}{\longrightarrow} \mathrm{OH}$ & + & + & + & ++ \\
\hline Contribution of shipping emissions to $\mathrm{OH}$ & - & + & ++ & + \\
\hline Contribution of shipping emissions to $\mathrm{HO}_{2}$ & - & - & $\circ$ & - \\
\hline
\end{tabular}

Large $\mathrm{NO}_{x}$ concentrations in the background (A and $\mathrm{B}$ ) impact the chemistry and net production efficiencies; i.e. the ozone enhancement per $\mathrm{NO}_{x}$ is decreasing with increasing $\mathrm{NO}_{x}$ concentrations (e.g. Dahlmann et al., 2011). The Reaction (R1), which transforms $\mathrm{HO}_{2}$ into $\mathrm{OH}$, in principle increases (decreases) the $\mathrm{OH}\left(\mathrm{HO}_{2}\right)$ concentration in the region where large amounts of shipping $\mathrm{NO}_{x}$ is present. However, this reaction only dominates the $\mathrm{OH}$ to $\mathrm{HO}_{2}$ ratio if enough ozone is available for the $\mathrm{HO}_{x}$ production. In region $\mathrm{A}$, the very low ozone concentration due to ozone titration by $\mathrm{NO}_{x}$ limits the availability of $\mathrm{OH}$ and the contribution of shipping $\mathrm{NO}_{x}$ to $\mathrm{OH}$ is even negative. Region $\mathrm{B}$ is less polluted than region $\mathrm{A}$ and has lower values of shipping $\mathrm{NO}_{x}$ and therefore Reaction (R1) dominates the $\mathrm{OH}$ and $\mathrm{HO}_{2}$ contributions from shipping, leading to positive contributions to $\mathrm{OH}$ and negative to $\mathrm{HO}_{2}$. The tagged shipping ozone is larger in area D compared to A and B (not shown). This leads to a larger contribution to $\mathrm{OH}$ via the main production reac- 


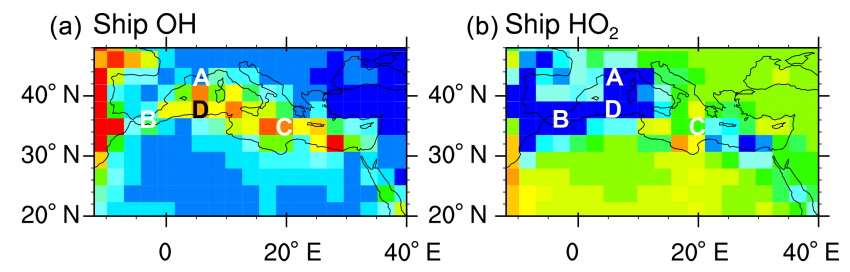

(b) Ship $\mathrm{HO}_{2}$

(c) Ship $\mathrm{OH}$
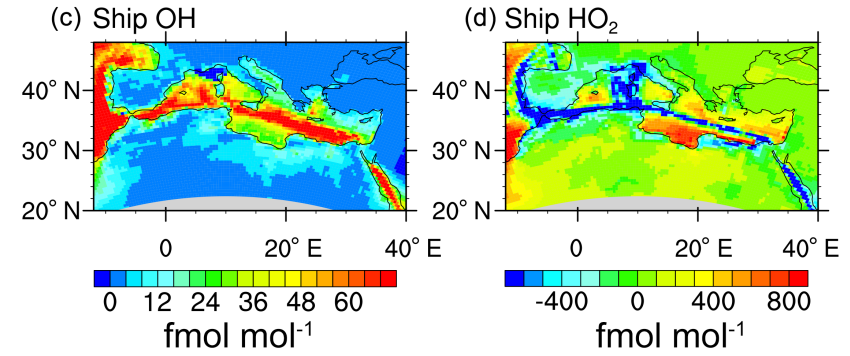

Figure 6. Absolute contribution of shipping to the simulated $\mathrm{OH}$ (a, c) and $\mathrm{HO}_{2}$ (b, d) volume mixing ratios (in fmol mol${ }^{-1}$ ) for August 2007. (a, b) EMAC; (c, d) $\operatorname{MECO}(n)$. Regions A-D are characterised by different chemical situations. A: southern France; B: Strait of Gibraltar; C: central Mediterranean Sea; D: Tunesian coast; see text for more details.

tion of $\mathrm{H}_{2} \mathrm{O}$ with $\mathrm{O}\left({ }^{1} \mathrm{D}\right)$, where the $\mathrm{O}\left({ }^{1} \mathrm{D}\right)$ originates from the tagged ozone (see also Table 3). The close coupling of $\mathrm{OH}$ with $\mathrm{HO}_{2}$ also enhances the tagged $\mathrm{HO}_{2}$ especially in region $\mathrm{D}$. These processes then lead to a complex picture. It shows negative contributions to $\mathrm{OH}$ in region $\mathrm{A}$, mainly due to low ozone concentration limiting the $\mathrm{OH}$ availability, which is even more pronounced by shipping emissions. The shipping contribution to $\mathrm{HO}_{2}$ in the polluted areas $\mathrm{A}$ and $\mathrm{B}$ are negative mainly driven by the Reaction (R1). Large positive contributions of shipping to $\mathrm{OH}$ and moderate negative contributions to $\mathrm{HO}_{2}$ are found in region $\mathrm{C}$, resulting from a combination of effects from Reaction (R1) and the main $\mathrm{OH}$ production resulting from tagged shipping ozone, whereas in region $\mathrm{D}$ moderate positive contributions of shipping to $\mathrm{OH}$ and large negative contributions to $\mathrm{HO}_{2}$ are found. Overall, the contributions from shipping emissions to the $\mathrm{OH}$ and $\mathrm{HO}_{2}$ concentrations show a complex picture, which results from variations in both the background concentrations and shipping concentrations. The impact of an enhanced horizontal resolution is discussed for the same situation in Sect. 5 .

Figure 7 shows annual mean contributions of aviation $\mathrm{NO}_{x}$ emissions to $\mathrm{OH}$ (left) and $\mathrm{HO}_{2}$ (right). The air traffic contribution to $\mathrm{OH}$ peaks at around $10-20 \mathrm{fmol} \mathrm{mol}^{-1}$ at the main flight altitude. At the surface, there are other secondary peaks, basically at the locations of the airports. Lee et al. (2010) summarised the work of Grewe et al. (2002) and Köhler et al. (2008) in their Fig. 10 and showed four atmospheric regions, which are affected differently by air traffic. In the first region $\left(\mathrm{RNO}_{y}\right.$ in their paper), which is mainly the air traffic corridor, Reaction (R1) controls the chemical impact from air traffic emissions. This implies that air traffic largely contributes to $\mathrm{OH}$ and negatively contributes to $\mathrm{RHO}_{2}$ as (a) Aviation $\mathrm{OH}$

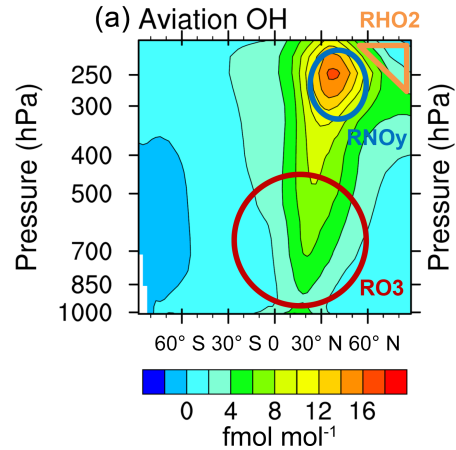

(b) Aviation $\mathrm{HO}_{2}$

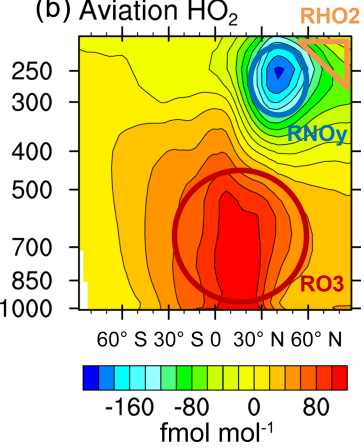

Figure 7. Annual mean absolute contribution $\left[\mathrm{fmol} \mathrm{mol}^{-1}\right]$ of aviation to the simulated $\mathrm{OH}$ (a) and $\mathrm{HO}_{2}$ (b) volume mixing ratios. The regions $\mathrm{RO}_{3}, \mathrm{RNO}_{y}$, and $\mathrm{RHO}_{2}$ are characterised by distinct different chemical response to aviation emissions as described by Grewe et al. (2002) (see text for further details).

shown in Fig. 7. The region north of $\mathrm{RNO}_{y}$ is called $\mathrm{RHO}_{2}$ and the aviation impact is largely controlled by the reaction of $\mathrm{O}_{3}$ with $\mathrm{HO}_{2}$ (see Table 3). Hence, this reaction leads to a reduction in $\mathrm{HO}_{2}$ without affecting the $\mathrm{OH}$ concentration in a similar manner. The region $\mathrm{RO}_{3}$ is located in the lower troposphere and away from the major flight corridor. Here, a significant contribution from air traffic to ozone is found, but not so much to $\mathrm{NO}_{y}$ (not shown). The region is controlled by an increase in ozone. Hence, it leads to a general increase in $\mathrm{HO}_{x}$ via the reaction of $\mathrm{H}_{2} \mathrm{O}$ with $\mathrm{O}\left({ }^{1} \mathrm{D}\right.$ ) (see Table 3). This comparison shows that the $\mathrm{OH}$ and $\mathrm{HO}_{2}$ contributions from aviation, calculated here, are consistent with the chemical regimes identified in previous studies.

A more detailed view on this tagging mechanism is feasible by applying it to a Lagrangian framework (Grewe et al., 2014). Within the EU-Project REACT4C (Reducing Emissions from Aviation by Changing Trajectories for the benefit of Climate), the $\mathrm{HO}_{x}$ tagging mechanism was implemented in the same EMAC model version, including a Lagrangian transport algorithm. Aviation-like pulse emissions of $\mathrm{NO}_{x}$ were released at selected points in the atmosphere, and trajectories with these emissions were tagged so that reactions with the background can be determined in detail. Note that aviation is not emitting CO and NMHCs in our simulation; hence, the equations look simplified in Grewe et al. (2014) as the values for $\mathrm{CO}^{\text {tag }}$ and $\mathrm{NMHC}^{\text {tag }}$ are zero (see Sect. 3.3). Figure 8 shows the temporal development of several $\mathrm{NO}_{x}$-related species (top and middle) as well as ozone production and loss terms (bottom) for a pulse emission at $45^{\circ} \mathrm{W}, 50^{\circ} \mathrm{N}$ and $300 \mathrm{hPa}$. The $\mathrm{NO}_{x}$ emission induces net production of $\mathrm{O}_{3}^{\text {tag }}$ (see Eq. 10 in Grewe et al., 2014), mainly via Reaction (R1) and enhanced $\mathrm{HO}_{x}^{\text {tag }}$ as calculated via Eqs. (29) and (30). $\mathrm{NO}_{x}$ reacts with $\mathrm{OH}$ and forms $\mathrm{HNO}_{3}$, which eventually leads to washout and a reduction of $\mathrm{NO}_{y}^{\mathrm{tag}}$ within a few weeks. When $\mathrm{NO}_{x}^{\mathrm{tag}}$ is no longer available for $\mathrm{O}_{3}$ production, $\mathrm{O}_{3}^{\text {tag }}$ is subsequently depleted. We denote the 

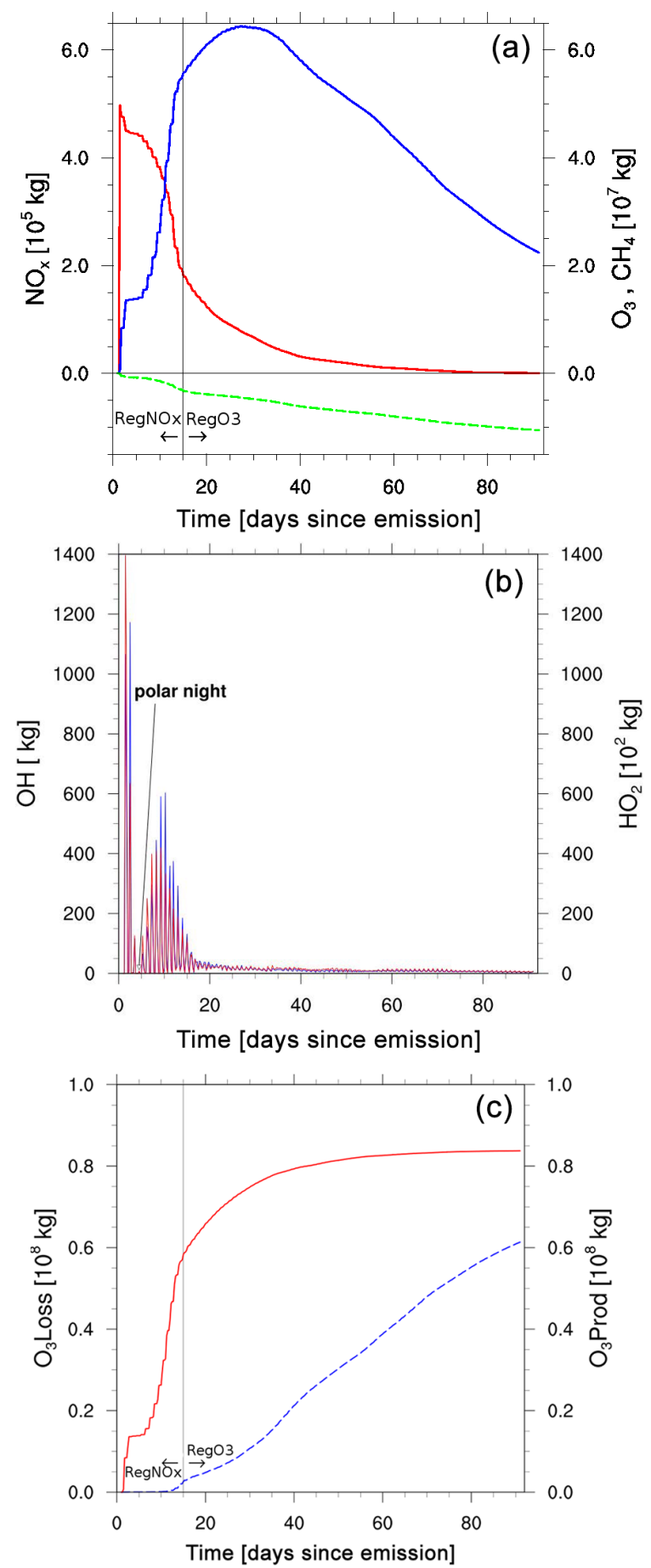

Figure 8. Temporal development of $\mathrm{NO}_{x}$-related species (a: $\mathrm{NO}_{x}$ (red), $\mathrm{O}_{3}$ (blue), $\mathrm{CH}_{4}$ (green), b: $\mathrm{OH}$ (blue), $\mathrm{HO}_{2}$ (red)) and production or loss terms (c: cumulative $\mathrm{O}_{3}$ loss (blue) and cumulative $\mathrm{O}_{3}$ production (red)) induced by a pulse emission at $45^{\circ} \mathrm{W}, 50^{\circ} \mathrm{N}$ and $300 \mathrm{hPa}$ on 23 December 2000. The discrimination between the regimes $\mathrm{RegNO}_{x}$ and $\mathrm{RegO}_{3}$ refers to the $\mathrm{NO}_{x}$ dominated (days 115 after emission) and the $\mathrm{O}_{3}$-dominated regime (days 16-90 after emission), respectively. chemical regime, where enough $\mathrm{NO}_{x}$ is available to produce larger amounts of ozone with $\mathrm{RegNO}_{x}$ and the following regime as $\mathrm{RegO}_{3}$ (see also Fig. 8). Regarding the destruction of $\mathrm{CH}_{4}^{\mathrm{tag}}$, these two regimes are also characterising the two different depletion pathways. First, as long as sufficient $\mathrm{NO}_{x}^{\mathrm{tag}}$ is available, $\mathrm{CH}_{4}^{\mathrm{tag}}$ is reduced because of an increase of $\mathrm{OH}^{\text {tag }}$ via reaction (R1) $\left(\mathrm{NO}_{x}\right.$-driven $\mathrm{CH}_{4}$ destruction). Second, when $\mathrm{NO}_{x}^{\text {tag }}$ is removed, $\mathrm{OH}^{\text {tag }}$ is mainly produced via photolysis of $\mathrm{O}_{3}^{\text {tag }}$ and the subsequent Reaction $P_{1}^{\mathrm{OH}}\left(\mathrm{H}_{2} \mathrm{O}\right.$ $+\mathrm{O}^{1} \mathrm{D} \rightarrow 2 \mathrm{OH}$ ). The tagged $\mathrm{OH}$ and $\mathrm{HO}_{2}$ are far lower in the $\mathrm{RegO}_{3}$ regime compared to the $\mathrm{RegNO}_{x}$ regime (Fig. 8, middle); consequently, the gradient in the $\mathrm{O}_{3}$-driven $\mathrm{CH}_{4}$ destruction is not as steep. However, due to the longer time period, it dominates the total amount of methane destruction in this case, which can be seen from a budget analysis for the chemical regimes $\mathrm{RegNO}_{x}$ (blue bars) and $\mathrm{RegO}_{3}$ (red bars) given in Fig. 9. Note that the trajectory is transported into polar night around day 5, which leads to a reduction of $\mathrm{OH}$ and $\mathrm{HO}_{2}$ and a reduction of the photochemical activity. This example shows a reasonable temporal behaviour of the tagged species and it further shows how combining the tagging methodology and a Lagrangian transport algorithm results in a powerful tool, facilitating a detailed analysis of particular processes.

\section{Sensitivities}

In this section, we investigate if our tagging scheme responds reasonably to changes in resolution (Sect. 5.1) and emissions (Sect. 5.2). In general, there are no strict verification tests other than checking for plausibility and stability.

\subsection{Higher resolution: $\operatorname{MECO}(n)$}

By applying the $\operatorname{MECO}(n)$ system (Kerkweg and Jöckel, 2012a, b; Hofmann et al., 2012; Mertens et al., 2016), we have increased the horizontal resolution over Europe by roughly a factor of 5 , from a resolution of roughly $200 \mathrm{~km}$ times $300 \mathrm{~km}$ in EMAC to $50 \mathrm{~km}$ times $50 \mathrm{~km}$ in the nested grid. Figure 10 shows the contributions of the individual emission sectors to the tropospheric ozone column as a mean over Europe for the coarse resolution (top) and the finer resolution (bottom). Clearly, the individual contributions are very similar in terms of mean values and the seasonal cycle. The finer-resolution simulation shows finer-resolved structures in the horizontal (not shown), which, however, do not largely affect the large-scale budgets.

As an example of the effects of finer resolution, we present $\mathrm{OH}$ and $\mathrm{HO}_{2}$ contributions from shipping over the Mediterranean Sea, as discussed in Sect. 4.3 and Fig. 6. The $\mathrm{OH}$ enhancement along shipping routes is much more visible in the finer-resolved case (Fig. 6, lower left) compared to the lower resolution (upper left). The structures for the $\mathrm{OH}$ and $\mathrm{HO}_{2}$ contributions are again similar: A positive contribution 


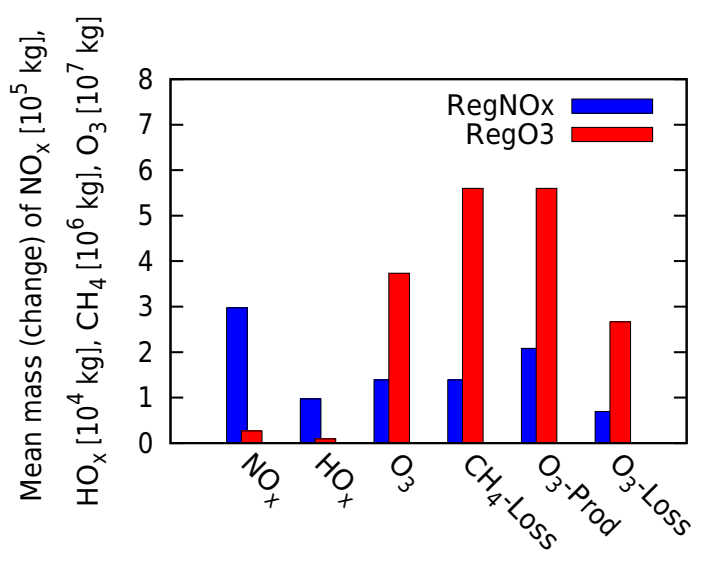

Figure 9. Mean contributions to $\mathrm{NO}_{x}$-related species and production or loss terms for the $\mathrm{RegNO}_{x}$ regime $\left(\mathrm{NO}_{x}\right.$ dominated, blue) and $\mathrm{RegO}_{3}$ regime $\left(\mathrm{O}_{3}\right.$ dominated, red), respectively. Values are given as temporal means over the two time periods.

to the $\mathrm{OH}$ concentration in the area of shipping emissions (B-D) and a decrease in the contribution to $\mathrm{OH}$ and $\mathrm{HO}_{2}$ where background $\mathrm{NO}_{x}$ is largely enhanced (region $\mathrm{A}$ ).

The comparison of the coarser and finer resolution clearly shows that the tagging scheme is stable in its behaviour. Naturally, the finer resolution enables more detailed and finerresolved chemical changes due to emissions to be quantified, but basic structures are reproduced in either resolution. This implies that, depending on the underlying research question, either model can be used.

\subsection{Emission changes}

We performed an additional global simulation with EMAC where we reduced the road traffic emissions by $5 \%$. The simulation set-up hence follows Hoor et al. (2009). This means that the chemical composition and the ozone productivity is different from the base simulation, which leads to a roughly $2-3 \%$ reduction in the tagged road traffic ozone (not shown). Generally, a reduction of surface $\mathrm{NO}_{x}$ emissions is increasing the ozone productivity (Emmons et al., 2012; Grewe et al., 2012) and consequently a $5 \%$ reduction in emissions is expected to lead to significantly less than a $5 \%$ reduction in road traffic ozone, which is consistent with our results. Figure 11 shows the relative change in tropospheric ozone induced by the road traffic emission reduction of $5 \%$. The total ozone change of $0.08 \%$ (black bar) is a consequence of the reduction of the contribution of road traffic to the tropospheric total ozone by $0.16 \%$ and other compensating effects. In total, this leads to a factor of 2 difference between the total ozone change and the road traffic ozone change. The compensating effects are resulting from larger net ozone production rates for the shipping emission sector and other anthropogenic non-traffic emission sectors. This leads to a larger contribution of the anthropogenic non-

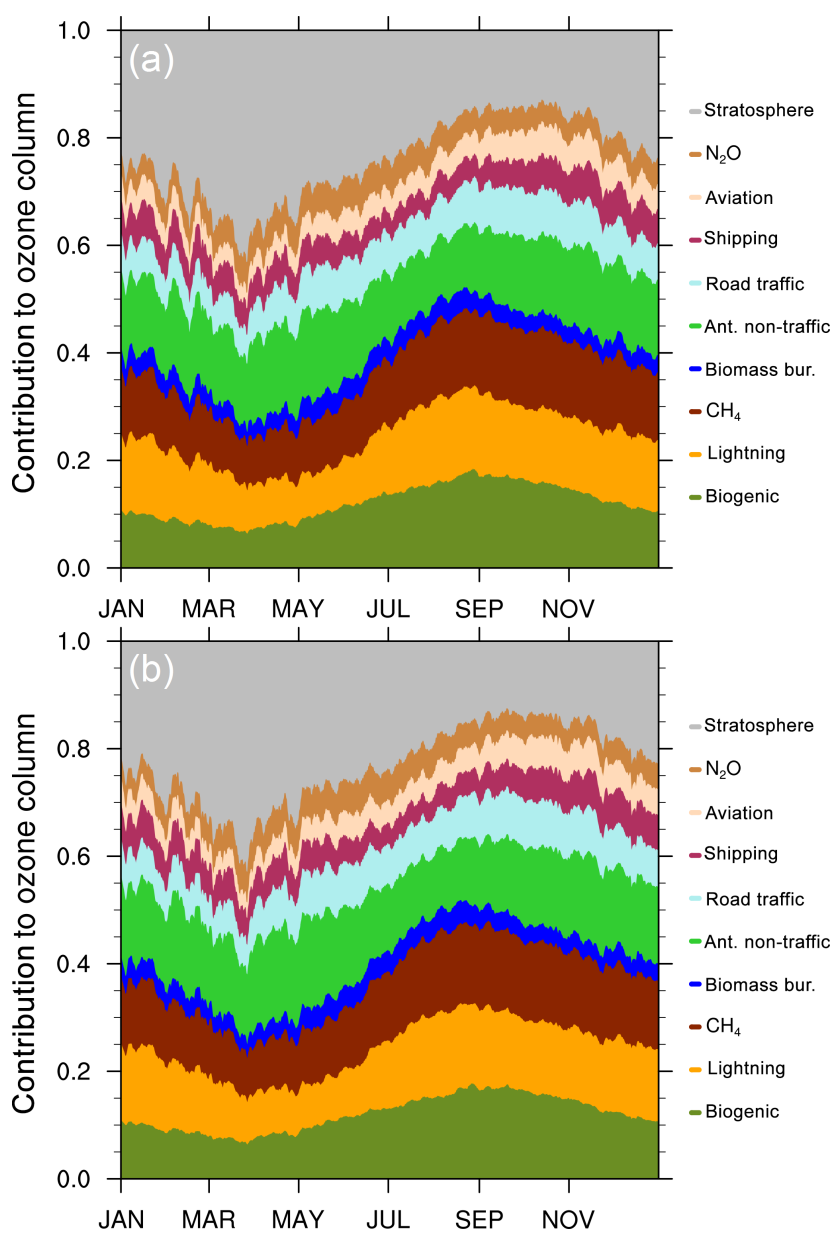

Figure 10. Contributions (fraction) of individual emission sectors to the European tropospheric ozone concentration for a coarserresolution simulation with EMAC (a) and a finer resolution with $\operatorname{MECO}(n)$ (b) for the year 2008.

traffic (dark blue bar) and the (other than road traffic) traffic emission sectors (green bar) to total ozone by 0.04 and $0.06 \%$, respectively. Other non-anthropogenic sectors (red bar), i.e. natural emission, reduce this compensation.

The ratio of 2 between the reduction in total ozone and road traffic indicates that a calculation of the road traffic contribution to tropospheric ozone using the perturbation method, i.e. difference between two simulations with changing emissions, underestimates this contribution by exactly this factor of 2. Other studies have shown slightly larger factors, e.g. a factor of 3 for biomass burning $\mathrm{NO}_{x}$ emissions (Emmons et al., 2012) and a factor of 5 for road traffic $\mathrm{NO}_{x}$ emissions (Grewe et al., 2012). Here, a smaller factor can be expected, since emissions other than $\mathrm{NO}_{x}$ and their impact on ozone are tagged, which reduces the effects from road traffic emission changes. Further, this factor largely depends on the chemical state of the atmosphere, which differ between the simulations. Hence, a direct intercomparison is not possible; however, the results are plausible. 


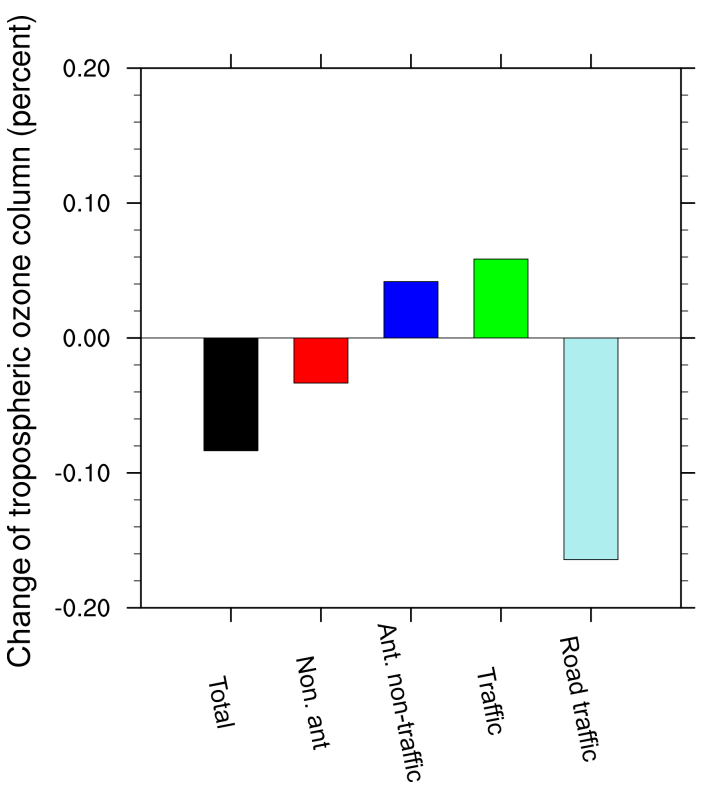

Figure 11. Changes in the global tropospheric ozone budget [\%] resulting from a $5 \%$ reduction in the road traffic emissions.

\section{Options, limitations, and future perspectives}

The primary goal for developing this TAGGING submodel is to diagnose the impact of many individual emission sectors on radiatively active species, such as ozone and methane (via $\mathrm{OH}$ as the main methane loss process), in multi-decadal simulations of the atmospheric composition. While this represents a major improvement in comparison to many available tagging mechanisms, it also has its limitations. Such a mechanism needs to be fast enough and to have a limited memory demand. It is a trade-off between complexity, accuracy, and even correctness. The approach presented in Sect. 2 is an accurate and self-consistent decomposition of concentrations with respect to processes considered. In order to limit the memory demand, we have mapped the complex chemistry scheme to a family concept, which reduces the number of required additional tracers to a minimum. Obviously, this mapping represents a loss in accuracy and in some cases unwanted and unphysical effects may occur. While the effect of mixing of tags through PAN processing is to some extent wanted (see discussion in Sect. 4.3), this also causes some unwanted effects. For example, during the degradation of methane, hydrocarbons are produced, which are classified as the NMHC family. In reality, they are not contributing to PAN formation, whereas in the tagging scheme, they are grouped in the NMHC category and thereby falsely contribute to PAN formation. Hence, the information on the type of hydrocarbons is lost in the family concept and represents an unphysical side effect. We might overcome these effects, at least to some extent by structuring the families in more detail. Such as different NMHC categories according to their number of $\mathrm{C}$ atoms. The coupling of families may represent a major problem, since tags are mixed unwantedly between the families for fast exchange rates. Here, we concentrate on effective exchanges only. Hence, the introduction of PAN buffers, PAN-NHMC and PAN-NO ${ }_{y}$, together with a PAN lifetime, may reduce this artefact. $\mathrm{NO}_{y}$ from one emission source, which forms PAN, will be accounted first in a buffer, which will decompose totally back to the original $\mathrm{NO}_{y}$ emission source. Only, for long lifetimes of the formed PAN, a mixing of tags could be allowed.

We presented for the first time a $\mathrm{HO}_{x}$ tagging mechanism, which provides reasonable information on how individual emission sources contribute to $\mathrm{OH}$ concentrations. Here, we also have mapped the $\mathrm{HO}_{x}$ chemistry to a reduced $\mathrm{HO}_{x}$ scheme. This leads to inaccuracies in the $\mathrm{OH}$ contributions, which are normally less than 10-20\%. First results show that an accuracy of less than $1 \%$ can be achieved if the complete mechanism is taken into account (Rieger et al., 2017), which will be presented in a forthcoming paper. However, the respective changes on $\mathrm{NO}_{y}$ and ozone are marginal.

\section{Conclusions}

We present a submodel for the Earth-System Model EMAC, which diagnoses online the contributions of individual source categories (mainly emission sectors) to the concentrations of various trace species. For the first time, we take into account the competition of nitrogen oxides, carbon monoxide and non-methane hydrocarbons for the production and destruction of ozone. We concentrated on 10 source categories and 7 species and families, which are tagged. As a result, we introduced 70 new tracers. The physical and chemical tendencies for these tracers are obtained from other submodels of EMAC, such as chemistry (MECCA), scavenging (SCAV), etc. The tagging mechanism is distributing the calculated physical and chemical tendencies into the tagged tracer fields. Therefore, the computing time increase by the TAGGING submodel is small, around $10 \%$.

We performed a present-day simulation and showed that the TAGGING submodel provides contributions of individual emission sectors to the concentration of ozone, which roughly agree with previous estimates. A detailed analysis of the calculated contribution of aviation and shipping to $\mathrm{OH}$ and $\mathrm{HO}_{2}$ shows reasonable results in different chemical regimes. Changes in the model's resolution show a stable performance of the TAGGING submodel. Changes in the strength of road traffic emissions yield a decrease in ozone, which is partly compensated for by an increase in ozone from other source categories, since the ozone production efficiency increases, which is in agreement with earlier findings (Grewe et al., 2012; Emmons et al., 2012).

The advantage of this specific tagging scheme is that (1) the effect of 10 source categories on ozone and other trace species can be monitored online in one simulation, (2) the competition between ozone precursors is included, (3) no lin- 
earisation is required, and (4) the scheme is applicable for long-term simulations, e.g. over a century. On the other hand, the disadvantage is that (1) the family concept is not flexible and fixed in this specific way, and consequently (2) any change in the set of chemical species requires an adaptation of the TAGGING scheme, and (3) due to memory limitations, a restriction to the main chemical species and families is required.

To summarise, the TAGGING submodel provides a powerful tool to identify the contribution of individual emission sectors to main atmospheric constituents at every grid point and time step of the simulation and can be further used to derive, for instance, radiative forcings or contribution to air quality information for individual emission sectors.

Code availability. The Modular Earth Submodel System (MESSy) is continuously further developed and applied by a consortium of institutions. The usage of MESSy and access to the source code is licensed to all affiliates of institutions, which are members of the MESSy Consortium. Institutions can become a member of the MESSy Consortium by signing the MESSy Memorandum of Understanding. More information can be found on the MESSy Consortium Website (http://www.messy-interface.org).

\section{The Supplement related to this article is available online at https://doi.org/10.5194/gmd-10-2615-2017- supplement.}

Competing interests. The authors declare that they have no conflict of interest.

Acknowledgements. This study has been conducted in the framework of the DLR projects VEU, VEU2 and WeCare. We gratefully acknowledge the computational resources provided by the Leibniz Supercomputing Centre (LRZ) in Garching and the German Climate Computing Centre (DKRZ) in Hamburg. We are thankful to Roland Eichinger, DLR, for a detailed internal review.

The article processing charges for this open-access

publication were covered by a Research

Centre of the Helmholtz Association.

Edited by: Fiona O'Connor

Reviewed by: two anonymous referees

\section{References}

Butler, T. M., Lawrence, M. G., Taraborrelli, D., and Lelieveld, J.: Multi-day ozone production potential of volatile organic compounds calculated with a tagging approach, Atmos. Environm. 45, 4082-4090, https://doi.org/10.1016/j.atmosenv.2011.03.040, 2012.
Crutzen, P. J. and Schmaizl, U.: Chemical budgets of the stratosphere, Planer. Space Sci. 31, 1009-1032, 1983.

Dahlmann, K., Grewe, V., Ponater, M., and Matthes, S.: Quantifying The Contributions Of Individual $\mathrm{NO}_{x}$ Sources To The Trend In Ozone Radiative Forcing, Atmos. Environm. 45, 2860-2868, https://doi.org/10.1016/j.atmosenv.2011.02.071, 2011.

Deckert, R., Jöckel, P., Grewe, V., Gottschaldt, K.-D., and Hoor, P.: A quasi chemistry-transport model mode for EMAC, Geosci Model Dev., 4, 195-206, https://doi.org/10.5194/gmd-4-1952011, 2011

Dee, D. P., Uppala, S. M., Simmons, A. J., Berrisford, P., Poli, P., Kobayashi, S., Andrae, U., Balmaseda, M. A., Balsamo, G., Bauer, P., Bechtold, P., Beljaars, A. C. M., van de Berg, I., Biblot, J., Bormann, N., Delsol, C., Dragani, R., Fuentes, M., Greer, A. J., Haimberger, L., Healy, S. B., Hersbach, H., Holm, E. V., Isaksen, L., Kallberg, P., Kohler, M., Matricardi, M., McNally, A. P., Mong-Sanz, B. M., Morcette, J.-J., Park, B.-K., Peubey, C., de Rosnay, P., Tavolato, C., Thepaut, J. N., and Vitart, F.: The ERAInterim reanalysis: Configuration and performance of the data assimilation system, Q. J. Roy. Meteorol. Soc., 137, 553-597, 2011.

Dunker, A. M., Yarwood, G., Ortmann, J. P., and Wilson, G. M.: Comparison of Source Apportionment and Source Sensitivity of Ozone in a Three-Dimensional Air Quality Model, Environ. Sci. Tech. 36, 2953-2964, https://doi.org/10.1021/es011418f, 2002.

Emmons, L. K., Hess, P. G., Lamarque, J.-F., and Pfister, G. G.: Tagged ozone mechanism for MOZART-4, CAM-chem and other chemical transport models, Geosci. Model Dev., 5, 15311542, https://doi.org/10.5194/gmd-5-1531-2012, 2012.

Granier, C., Bessagnet, B., Bond, T., D’Angiola, A., van der Gon, H. D., Frost, G., Heil, A., Kaiser, J., Kinne, S., Klimont, Z., Kloster, S., Lamarque, J.-F., Liousse, C., Masui, T., Meleux, F., Mieville, A., Ohara, T., Raut, J.-C., Riahi, K., Schultz, M., Smith, S., Thompson, A., Aardenne, J., Werf, G., and Vuuren, D.: Evolution of anthropogenic and biomass burning emissions of air pollutants at global and regional scales during the 1980-2010 period, Clim. Change, 109, 163-190, https://doi.org/10.1007/s10584011-0154-1, 2011.

Grewe, V.: Technical Note: A diagnostic for ozone contributions of various $\mathrm{NO}_{x}$ emissions in multi-decadal chemistryclimate model simulations, Atmos. Chem. Phys., 4, 729-736, https://doi.org/10.5194/acp-4-729-2004, 2004

Grewe, V.: Impact of climate variability on tropospheric ozone, Sci. Total Environ., 374, 167-81, 2007.

Grewe, V.: A new method to diagnose the contribution of anthropogenic activities to temperature: temperature tagging, Geosci. Model Dev., 6, 417-427, https://doi.org/10.5194/gmd-6-4172013, 2013a.

Grewe, V.: A generalized tagging method, Geosci. Model Dev., 6, 247-253, https://doi.org/10.5194/gmd-6-247-2013, 2013b.

Grewe, V., Brunner, D., Dameris, M., Grenfell, J.L., Hein, R., Shindell, D., and Staehelin, J., Origin and variability of upper tropospheric nitrogen oxides and ozone at northern mid-latitudes, Atmos. Environ. 35, 3421-3433, 2001.

Grewe, V., Dameris, M., Fichter, C., and Lee, D.: Impact of aircraft $\mathrm{NO}_{x}$ emissions, Part 2: Effects of lowering the flight altitude, Meteorol. Z., 3, 197-205, 2002.

Grewe, V., Stenke, A., Ponater, M., Sausen, R., Pitari, G., Iachetti, D., Rogers, H., Dessens, O., Pyle, J., Isaksen, I. S. A., Gulstad, 
L., Søvde, O. A., Marizy, C., and Pascuillo, E.: Climate impact of supersonic air traffic: an approach to optimize a potential future supersonic fleet - results from the EU-project SCENIC, Atmos. Chem. Phys., 7, 5129-5145, https://doi.org/10.5194/acp-7-51292007, 2007.

Grewe, V., Tsati, E., and Hoor, P.: On the attribution of contributions of atmospheric trace gases to emissions in atmospheric model applications, Geosci. Model Dev., 3, 487-499, https://doi.org/10.5194/gmd-3-487-2010, 2010.

Grewe, V., Dahlmann, K., Matthes, S., and Steinbrecht, W.: Attributing ozone to $\mathrm{NO}_{x}$ emissions: Implications for climate mitigation measures, Atmos. Environ., 59, 102-107, 2012.

Grewe, V., Frömming, C., Matthes, S., Brinkop, S., Ponater, M., Dietmüller, S., Jöckel, P., Garny, H., Tsati, E., Dahlmann, K., Søvde, O. A., Fuglestvedt, J., Berntsen, T. K., Shine, K. P., Irvine, E. A., Champougny, T., and Hullah, P.: Aircraft routing with minimal climate impact: the REACT4C climate cost function modelling approach (V1.0), Geosci. Model Dev., 7, 175-201, https://doi.org/10.5194/gmd-7-175-2014, 2014.

Gromov, S., Jöckel, P., Sander, R., and Brenninkmeijer, C. A. M.: A kinetic chemistry tagging technique and its application to modelling the stable isotopic composition of atmospheric trace gases, Geosci. Model Dev., 3, 337-364, https://doi.org/10.5194/gmd-3337-2010, 2010.

Guenther, A., Hewitt, C., E., D., Fall, R. G., C., Graedel, T., Harley, P., Klinger, L., Lerdau, M., McKay, W., Pierce, T., S., B., Steinbrecher, R., Tallamraju, R., Taylor, J., and Zimmermann, P.: A global model of natural volatile organic compound emissions, J. Geophys. Res., 100, 8873-8892, 1995.

Hofmann, C., Kerkweg, A., Wernli, H., and Jöckel, P.: The 1-way on-line coupled atmospheric chemistry model system $\operatorname{MECO}(n)$ - Part 3: Meteorological evaluation of the on-line coupled system, Geosci. Model Dev., 5, 129-147, https://doi.org/10.5194/gmd-5-129-2012, 2012.

Hoor, P., Borken-Kleefeld, J., Caro, D., Dessens, O., Endresen, O., Gauss, M., Grewe, V., Hauglustaine, D., Isaksen, I. S. A., Jöckel, P., Lelieveld, J., Myhre, G., Meijer, E., Olivie, D., Prather, M., Schnadt Poberaj, C., Shine, K. P., Staehelin, J., Tang, Q., van Aardenne, J., van Velthoven, P., and Sausen, R.: The impact of traffic emissions on atmospheric ozone and $\mathrm{OH}$ : results from QUANTIFY, Atmos. Chem. Phys., 9, 3113-3136, https://doi.org/10.5194/acp-9-3113-2009, 2009.

Horowitz, L. and Jacob, D., Global impact of fossil fuel combustion on atmospheric $\mathrm{NO}_{x}$, J. Geophys. Res., 104, 23823-23840, https://doi.org/10.1029/1999JD900205, 1999.

Jöckel, P., Sander, R., Kerkweg, A., Tost, H., and Lelieveld, J.: Technical Note: The Modular Earth Submodel System (MESSy) - a new approach towards Earth System Modeling, Atmos. Chem. Phys., 5, 433-444, https://doi.org/10.5194/acp-5-4332005, 2005.

Jöckel, P., Tost, H., Pozzer, A., Brühl, C., Buchholz, J., Ganzeveld, L., Hoor, P., Kerkweg, A., Lawrence, M. G., Sander, R., Steil, B., Stiller, G., Tanarhte, M., Taraborrelli, D., van Aardenne, J., and Lelieveld, J.: The atmospheric chemistry general circulation model ECHAM5/MESSy1: consistent simulation of ozone from the surface to the mesosphere, Atmos. Chem. Phys., 6, 50675104, https://doi.org/10.5194/acp-6-5067-2006, 2006.

Jöckel, P., Kerkweg, A., Buchholz-Dietsch, J., Tost, H., Sander, R., and Pozzer, A.: Technical Note: Coupling of chemical pro- cesses with the Modular Earth Submodel System (MESSy) submodel TRACER, Atmos. Chem. Phys., 8, 1677-1687, https://doi.org/10.5194/acp-8-1677-2008, 2008.

Jöckel, P., Kerkweg, A., Pozzer, A., Sander, R., Tost, H., Riede, H., Baumgaertner, A., Gromov, S., and Kern, B.: Development cycle 2 of the Modular Earth Submodel System (MESSy2), Geosci. Model Dev., 3, 717-752, https://doi.org/10.5194/gmd-3717-2010, 2010.

Jöckel, P., Tost, H., Pozzer, A., Kunze, M., Kirner, O., Brenninkmeijer, C. A. M., Brinkop, S., Cai, D. S., Dyroff, C., Eckstein, J., Frank, F., Garny, H., Gottschaldt, K.-D., Graf, P., Grewe, V., Kerkweg, A., Kern, B., Matthes, S., Mertens, M., Meul, S., Neumaier, M., Nützel, M., Oberländer-Hayn, S., Ruhnke, R., Runde, T., Sander, R., Scharffe, D., and Zahn, A.: Earth System Chemistry integrated Modelling (ESCiMo) with the Modular Earth Submodel System (MESSy) version 2.51, Geosci. Model Dev., 9, 1153-1200, https://doi.org/10.5194/gmd-9-1153-2016, 2016.

Kerkweg, A. and Jöckel, P.: The 1-way on-line coupled atmospheric chemistry model system $\operatorname{MECO}(n)-$ Part 1: Description of the limited-area atmospheric chemistry model COSMO/MESSy, Geosci. Model Dev., 5, 87-110, https://doi.org/10.5194/gmd-587-2012, 2012a.

Kerkweg, A. and Jöckel, P.: The 1-way on-line coupled atmospheric chemistry model system $\operatorname{MECO}(n)-$ Part 2: On-line coupling with the Multi-Model-Driver (MMD), Geosci. Model Dev., 5, 111-128, https://doi.org/10.5194/gmd-5-111-2012, 2012b.

Kerkweg, A., Buchholz, J., Ganzeveld, L., Pozzer, A., Tost, H., and Jöckel, P.: Technical Note: An implementation of the dry removal processes DRY DEPosition and SEDImentation in the Modular Earth Submodel System (MESSy), Atmos. Chem. Phys., 6, 4617-4632, https://doi.org/10.5194/acp-6-4617-2006, 2006a.

Kerkweg, A., Sander, R., Tost, H., and Jöckel, P.: Technical note: Implementation of prescribed (OFFLEM), calculated (ONLEM), and pseudo-emissions (TNUDGE) of chemical species in the Modular Earth Submodel System (MESSy), Atmos. Chem. Phys., 6, 3603-3609, https://doi.org/10.5194/acp-6-3603-2006, 2006b.

Köhler, M. O., Rädel, G., Dessens, O., Shine, K. P., Rogers, H. L., Wild, O., and Pyle, J. A.: Impact of perturbations to nitrogen oxide emissions from global aviation, J. Geophys. Res. 113, D11305, https://doi.org/10.1029/2007JD009140, 2008.

Lamarque, J.-F., Hess, P., Emmons, L., Buja, L., Washington, W., and Granier, C.: Tropospheric ozone evolution between 1890 and 1990, J. Geophys. Res., 110, D08304, https://doi.org/10.1029/2004JD005537, 2005.

Landgraf, J. and Crutzen, P. J.: An efficient method for online calculations of photolysis and heating rates, J. Atmos. Sci., 55, 863878, 1998.

Lee, D. S., Pitari, G., Grewe, V., Gierens, K., Penner, J. E., Petzold, A., Prather, M. J., Schumann, U., Bais, A., Berntsen, T., Iachetti, D., Lim, L. L., and Sausen, R.: Transport impacts on atmosphere and climate: Aviation, Atmos. Environm., 44, 4678-4734, 2010.

Lelieveld, J. and Dentener, F. J.: What conrols tropospheric chemistry, J. Geophys. Res., 105, 3531-3551, 2000.

Meijer, E., van Velthoven, P., Thompson, A., Pfister, L., Schlager, H., Schulte, P., and Kelder, H.: Model calculations of the impact of $\mathrm{NO}_{x}$ from air traffic, lightning, and surface emissions, compared withmeasurements, J. Geophys. Res., 105, 3833-3850, 2000 . 
Mertens, M., Kerkweg, A., Jöckel, P., Tost, H., and Hofmann, C.: The 1-way on-line coupled model system $\operatorname{MECO}(n)-$ Part 4: Chemical evaluation (based on MESSy v2.52), Geosci. Model Dev., 9, 3545-3567, https://doi.org/10.5194/gmd-9-3545-2016, 2016.

Price, C. and Rind, D.: A simple lightning parameterization for calculating global lightning distributions, J. Geophys. Res., 97, 9919-9933 https://doi.org/10.1029/92JD00719, 1992.

Roberts, J. M.: PAN and related compounds, in: Volatile Organic Compounds in the Atmosphere, edited by: Koopmann, R., Blackwell Publishing Ltd., 221-268, 2007.

Rieger, V. S., Mertens, M., and Grewe V.: Further development of the TAGGING submodel 1.x based on the Modular Earth Submodel System (MESSy 2.53): An enhanced method of contributing emissions to short-lived chemical species $\left(\mathrm{OH}\right.$ and $\left.\mathrm{HO}_{2}\right)$, Geosci. Model Dev., in preparation, 2017.

Roeckner, E., Bäuml, G., Bonaventura, L., Brokopf, R., Esch, M., Giorgetta, M., Hagemann, S., Kirchner, I., Kornblueh, L., Manzini, E., Rhodin, A., Schlese, U., Schulzweida, U., and Tompkins, A.: The atmospheric general circulation model ECHAM5. PART I: Model description, Tech. rep., Max Planck Institute for Meteorology, MPI-Report 349, available at: http://www.mpimet.mpg.de/fileadmin/publikationen/Reports/ max_scirep_349.pdf, 2003.

Sander, R., Baumgaertner, A., Gromov, S., Harder, H., Jöckel, P., Kerkweg, A., Kubistin, D., Regelin, E., Riede, H., Sandu, A., Taraborrelli, D., Tost, H., and Xie, Z.-Q.: The atmospheric chemistry box model CAABA/MECCA-3.0, Geosci. Model Dev., 4, 373-380, https://doi.org/10.5194/gmd-4-373-2011, 2011.
Sillman, S.: The use of NOy, $\mathrm{H}_{2} \mathrm{O}_{2}$ and $\mathrm{HNO}_{3}$ a for $\mathrm{O}_{3}-\mathrm{NO}_{x}-\mathrm{VOC}$ sensitivity in urban locations, J. Geophys. Res., 100, 1417514188, 1995.

Tost, H., Jöckel, P., and Lelieveld, J.: Influence of different convection parameterisations in a GCM, Atmos. Chem. Phys., 6, 54755493, https://doi.org/10.5194/acp-6-5475-2006, 2006 a.

Tost, H., Jöckel, P., Kerkweg, A., Sander, R., and Lelieveld, J.: Technical note: A new comprehensive SCAVenging submodel for global atmospheric chemistry modelling, Atmos. Chem. Phys., 6, 565-574, https://doi.org/10.5194/acp-6-565-2006, 2006 b.

Tost, H., Jöckel, P., and Lelieveld, J.: Lightning and convection parameterisations - uncertainties in global modelling, Atmos. Chem. Phys., 7, 4553-4568, https://doi.org/10.5194/acp-7-45532007, 2007.

Tsati, E.-E.: Investigation of the impacts of emissions on the trace gas budgets in the troposphere by using global climate chemistry model simulations, Dissertation, Ludwig-MaximiliansUniversität München, Fakultät für Physik, available at: http: //nbn-resolving.de/urn:nbn:de:bvb:19-175246, 2014.

Yienger, J. J. and Levy II, H. L.: Global inventory of soil-biogenic $\mathrm{NO}_{x}$ emissions, J. Geophys. Res., 100, 11447-11464, 1995. 